\title{
BANCANDO A LIBERDADE, POPULARIZANDO A POLÍTICA: \\ ABOLICIONISMO E FUNDOS LOCAIS DE EMANCIPAÇÃO \\ NA DÉCADA DE 1880 NO BRASIL*
}

Celso Castilho**

Camillia Cowling ${ }^{* * *}$

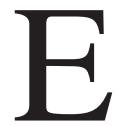

m 1881, Maria, escrava doméstica e moradora da cidade do Recife, remeteu uma carta a João Ramos, secretário da Sociedade Nova Emancipadora. Uma entre a pletora de sociedades abolicionistas surgindo pelo Brasil no início da década de 1880, a Sociedade Nova Emancipadora operava um fundo de emancipação para escravos. Assim como outras pessoas escravizadas, Maria estava plenamente consciente das possibilidades representadas pela Sociedade Nova Emancipadora. Seu pedido a Ramos, a quem ela aparentemente conhecera antes, era por um empréstimo de 100 mil réis, a quantia que lhe faltava em suas economias para comprar sua liberdade. Maria implorou, em nome de "Deus, da caridade... e da esposa e filho de João Ramos", que ele recordasse o que havia "prometido" a ela. Sublinhando as

Tradução de Marília Bueno de Araújo Ariza. Agradecemos as equipes do Arquivo Geral da Cidade do Rio de Janeiro, do Arquivo Público Estadual de Pernambuco e do Instituto Arqueológico Histórico e Geográfico Pernambucano. Ao comitê editorial e aos pareceristas da AfroÁsia. Agradecemos ao Institute for the Study of Slavery (University of Nottingham, UK), o Leverhulme Trust (UK), a University of California, Berkley, e a Comissão Fullbright pelo financiamento de pesquisa.

** Celso Castilho é professor assistente de História da Universidade de Vanderbilt, Estados Unidos. celso.t.castilho@vanderbilt.edu

**** Camillia Cowling é professora assistente de História da Universidade de Edimburgo, Reino Unido. camillia.cowling@ed.ac.uk 
dificuldades de ganhar dinheiro para sua liberdade, Maria acrescentou: "para uma escrava como eu não há nem um dia Santo ou um domingo em que eu possa sair". Sua petição terminava em aflição: "Senhor, você não pode imaginar como vivo nessa casa, observando meu senhor bater em minhas três filhas libertas e chamá-las de escravas, sem nada poder fazer...". ${ }^{1}$

Em outro instante e em outro lugar, outra mulher também evocou seu status de "mãe" para pleitear a liberdade da filha. Em 1886, na capital do império, a uns 2.400 quilômetros de distância do Recife, Maria Rosa enviou uma petição à imperatriz Teresa Cristina, esposa do imperador Pedro II. ${ }^{2}$ Em pouco tempo, Teresa Cristina presidiria uma cerimônia de libertação de escravos, que formaria parte de uma série de pródigas cerimônias de libertação por meio do fundo de emancipação da Câmara Municipal, o Livro de Ouro. Embora Maria Rosa não fosse, como a Maria do Recife, uma escrava, mas sim uma mulher negra liberta e pobre, ela também evocou seu status de mãe de modo a angariar simpatias à sua solicitação. Ela pediu que sua filha escravizada, Ludovina, "uma infeliz criatura a qual está quase sempre inferma [sic] á [sic] ponto de butar [sic; botar] sangue pela bocca [sic], e com três filhos menores", fosse liberta na próxima cerimônia. Maria Rosa evocou a família de Teresa Cristina, além da sua própria, desejando-lhe longos anos de felicidade "junto de sua Augusta Família".

Este artigo investiga como os fundos locais de emancipação usados por Maria e Maria Rosa, no Recife e Rio de Janeiro, respectivamente, tornaram-se foco central para a participação política popular que

Maria para João Ramos, s.d., [data aproximada, 1881] Instituto Arqueológico Histórico e Geográfico Pernambucano (de aqui em diante IAHGP), Coleção João Ramos (de aqui em diante, CJR). Não está claro se a autoria dessa carta, escrita em primeira pessoa, é da própria Maria, ou se ela recorreu ao auxílio de um escriba ou algum conhecido alfabetizado que tenha redigido a carta. A mesma incerteza existe no que diz respeito à maioria dos registros escritos de brasileiros que não integravam as elites locais, como discutido nesse e em outros artigos. A respeito do uso da escrita por escravos, ver Sandra Lauderdale Graham, "Writing from the Margins: Brazilian Slaves and Written Culture", Comparative Studies in Society and History, v. 49 , n. 3 (2007), pp. 611-36.

2 Nesse artigo, a menção ao "Rio de Janeiro" implica a cidade e não a província circundante, a não ser quando indicado. "Corte" e "Município Neutro", termos coevos para a cidade, são também usados de forma intercambiável.

3 Maria Rosa para Imperatriz Teresa Cristina, Arquivo Geral da Cidade do Rio de Janeiro (daqui em diante referido como AGCRJ), Coleção Escravidão, Emancipação (daqui por diante E:E), Livro 6.1.41, 6 de março de 1886, p. 35. 
caracterizou o abolicionismo brasileiro na década de $1880 .{ }^{4}$ Os fundos locais de emancipação foram parte de uma resposta orquestrada ao lento progresso do programa do governo para a emancipação gradual - a "Lei do Ventre Livre", de 1871. ${ }^{5}$ A lei estabelecia que crianças nascidas de mulheres escravizadas após 28 de setembro de 1871 seriam consideradas legalmente livres. Ademais, o artigo três da mesma lei estipulava a criação de um fundo nacional de emancipação para reduzir a população de 1,5 milhões de escravos no Brasil. Em meados da década de 1880, entretanto, era evidente que o fundo de emancipação nacional provara-se uma frágil estratégia de abolição, tendo libertado menos de $1 \%$ da população escravizada durante uma década de vigência. ${ }^{6}$ Os abolicionistas, assim, desaprovavam o ritmo moroso da "Lei do Ventre Livre", pois, para eles, sob tal moldura emancipacionista, a escravidão teria resistido à entrada no século $\mathrm{XX}{ }^{7}$

A frustração dos abolicionistas com o fundo nacional influenciou a maneira como os historiadores lidaram - ou, de maneira geral, não lidaram - com as implicações dos fundos de emancipação privados e municipais que surgiam pelo Brasil na década de $1880 .{ }^{8}$ Durante essa

4 Diferenças conceituais distinguem abolicionismo e emancipacionismo. Ao contrário do primeiro termo, que se refere à mobilização popular para o fim da escravidão, o segundo envolve programas cujos objetivos eram a restrição da escravidão. Medidas emancipacionistas refletiam a posição do governo nacional que, até a Lei de abolição definitiva em 13 de maio de 1888, nunca endossou um projeto que estabelecesse uma data fixa para o término da escravidão. "Antiescravista" nesse artigo refere-se a atitudes críticas à escravidão. Tais opiniões são tão antigas quanto a própria instituição da escravidão; ainda assim, durante os anos da década de 1880, setores populares transformaram o sentimento antiescravista em ações coletivas e abolicionistas cujo intuito era o de dar fim á escravidão. Nossa compreensão desses termos é tributária de Christopher Leslie Brown, Moral Capital: Foundations of British Abolitionism, Chapel Hill: University of North Carolina Press, 2006, p. 17; e Célia Maria Marinho de Azevedo, Abolitionism in the United States and Brazil: A Comparative Perspective, Nova York: Garland Publishing, 1995, p. 34.

5 Usamos aspas para refletir o fato de que a lei não foi imediatamente reconhecida como "Lei do Ventre Livre" à época. O exato status legal dos ventres de mulheres escravizadas permanecia indefinido por lei, sendo, de maneira contrária, negociado de formas complexas depois - o que acarretava implicações políticas fundamentais no que dizia respeito ao status dessa geração de crianças que se tornaram gradualmente conhecidas como "ingênuos". Mantemos o termo porque, em retrospecto, tornou-se uma taquigrafia geral para esta lei. Ver Sidney Chalhoub, Machado de Assis, historiador, São Paulo: Companhia das Letras, 2003, pp. 171-82, 266-9.

6 Evaristo de Moraes, A campanha abolicionista, 1879-1888, Brasília: Editora da Universidade de Brasília, 1986 [1924], p. 24.

7 Joaquim Nabuco, O abolicionismo, ed. fac-similar, Recife: Editora Massangana, 1988 [1883], p. 207.

8 Para exemplos de fundos locais em Porto Alegre, Paraíba do Norte, Petrópolis, Paraíba do Sul e Bahia, ver Roger Kittleson, "Women and Notions of Womanhood in Brazilian Abolitionism", in Pamela Scully e Diana Paton (orgs.), Gender and Slave Emancipation in the Atlantic World (Durham: Duke University Press, 2005), pp. 99-120. 
década, os fundos foram parte fundamental da mobilização popular descentralizada que transformava a arena política brasileira. Ainda assim, a historiografia da emancipação compensada concentrou-se no pequeno número de manumissões alcançadas pelo governo nacional a través da "Lei do Ventre Livre" de 1871. ${ }^{9}$ Talvez aplicando um raciocínio similar aos fundos privados e municipais, historiadores não os têm considerado merecedores de atenção. Entretanto, histórias como aquelas de Maria ou Maria Rosa, e como as dos fundos de emancipação locais emaranhados em seus destinos, certamente merecem ser ouvidas. Elas revelam atividades intrigantes e complexas de atores sociais e políticos da sociedade imperial, conectando escravos a abolicionistas, políticos de esfera municipal e nacional e até mesmo a família imperial. As mulheres, escravizadas ou livres, eram as principais beneficiárias dos fundos e tornaram-se importantes agentes no processo que daqui em diante chamaremos de 'bancar a liberdade'. Essas histórias são utilizadas aqui como um fio condutor para analisar um universo social muito mais amplo de atividades abolicionistas, prestando-se também à função de promover novos questionamentos sobre gênero e cidadania no Brasil. ${ }^{10}$

Este artigo utiliza a prática abolicionista de "bancar" a liberdade para esclarecer como a mobilização popular pela abolição produziu resultados específicos em relação à liberdade de indivíduos, e ao mesmo

9 Conrad, Destruction, pp. 104-5, 110-16; Maria Lúcia Lamounier, "Between Slavery and Free Labour: Experiments with Free Labour and Patterns of Slave Emancipation in Brazil and Cuba c.1830-1888" (Tese de Doutorado, London School of Economics, 1993), pp. 300-6; Emília Viotti da Costa, The Brazilian Empire: Myths and Histories, revised ed., Chapel Hill: University of North Carolina Press, 2000, p. 165. Para uma reavaliação do fundo nacional de emancipação, ver: Fabiano Dauwe, "A libertação gradual e a saída viável: os múltiplos sentidos da liberdade pelo fundo de emancipação de escravos" (Dissertação de Mestrado, Universidade Federal Fluminense, Niterói, 2004), pp. 9-33.

${ }^{10}$ Os temas do envolvimento de mulheres e do discurso de gênero no abolicionismo brasileiro receberam alguma atenção dos historiadores, mas permanecem relativamente pouco pesquisados. Ver: Camillia Cowling, "Debating Womanhood, Defining Freedom: The Abolition of Slavery in 1880s Rio de Janeiro", Gender \& History, v. 22, n. 2 (2010), pp. 284-301; Kittleson, "Women and Notions of Womanhood"; Roger A. Kittleson, "Campaign of All Peace and Charity: Gender and the Politics of Abolitionism in Porto Alegre, Brazil, 1846-1888", Slavery and Abolition, n. 22 (2001), pp. 83-108; Luzilá Gonçalves Ferreira, "A luta das mulheres pernambucanas", in Luzilá Gonçalves Ferreira et. alli. (orgs.), Suaves amazonas: mulheres e abolição da escravatura no nordeste (Recife: Editora UFPE, 1999), pp. 41-110; June E. Hahner, Emancipating the Female Sex: The Struggle for Women's Rights in Brazil, 1850-1940, Durham: Duke University Press, 1990. A dissertação de Wiebke Ipsen também destaca o papel das mulheres de elite na caridade e cerimônias públicas durante a Guerra do Paraguai. Ver: Ipsen, "Delicate Citizenship: Gender and Nationbuilding in Brazil, 1865-1891" (Tese de Doutorado, University of California, Irvine, 2005). 
tempo também ampliou as concepções sobre a esfera pública no final do Brasil oitocentista. ${ }^{11}$ Com atenção em duas variedades de fundos locais de emancipação - a primeira, iniciativas privadas do movimento abolicionista do Recife; e a segunda, um fundo municipal na cidade do Rio de Janeiro - focamos em dois tipos diferentes de pressão abolicionista, dentro de dois contextos urbanos em regiões bastante distintas no Brasil, cada qual ligada à outra e aos desdobramentos do contexto da política parlamentar.

Os fundos locais emergiram num contexto político em que a abolição permanecia altamente contenciosa, sendo a escravidão um baluarte do edifício político brasileiro desde a independência. ${ }^{12}$ Elites escravistas continuavam a exercer forte influência sobre as políticas do governo nacional de um país onde a posse da terra e a influência política caminhavam de mãos dadas, e que permanecia predominantemente rural, embora passasse por um rápido processo de urbanização e fosse marcado pela crescente variação regional nos padrões de propriedade escrava. ${ }^{13}$ Recife, no centro da província açucareira de Pernambuco, era um dos primeiros enclaves de riqueza e poder baseados na propriedade escrava do Brasil. Ainda assim, sendo a terceira maior cidade do Brasil oitocentista, produziu um forte movimento abolicionista urbano, bem como políticos que moldaram a agenda antiescravista do parlamento nacional. ${ }^{14}$ Ao mesmo tempo, a capital nacional, em rápida ex-

11 Fonte de debate historiográfico por mais de um século, o papel dos abolicionistas no processo de emancipação tem sido, em momentos diferentes, exaltado, ignorado ou menosprezado. Nossa intenção distingue-se claramente do intuito de engrandecer ou contribuir para a confecção do mito do movimento abolicionista em geral ou de quaisquer figuras em particular; pelo contrário, sugerimos que o movimento oferece uma estrutura para abordar, conjuntamente, as dimensões políticas e sociais da abolição. Para uma revisão recente da historiografia do abolicionismo brasileiro que aponta uma renovada necessidade de estudar o movimento abolicionista, ver: Barbara Weinstein, "The Decline of the Progressive Planter and the Rise of the Subaltern Agency: Shifting Narratives of Slave Emancipation in Brazil", in Gilbert Joseph (org.), Reclaiming the Political in Latin American History: Essays from the North (Durham: Duke University Press, 2001), p. 84.

12 Ver: Ilmar Rohloff de Mattos, O tempo Saquarema, São Paulo: Hucitec, 1987. Ver também Márcia Regina Berbel e Rafael de Bivar Marquese, "The Absence of Race: Slavery, Citizenship, and Pro-Slavery Ideology in the Cortes of Lisbon and the Rio de Janeiro Constituent Assembly (1821-4)", Social History, v. 32, n. 4 (2007), pp. 415-33.

13 Richard Graham, Patronage and Politics in Nineteenth-Century Brazil, Stanford: Stanford University Press, 1990, p. 16.

14 Para uma visão abrangente das políticas antiescravistas em Pernambuco, ver: Celso Castilho, "Abolitionism Matters: The Politics of Antislavery in Pernambuco, 1869-1888" (Tese de Doutorado, University of California, 2008). 
pansão, situava-se no coração da fortemente escravista província cafeicultura do Rio de Janeiro. O bancamento da liberdade provocou duradouras tensões políticas dentro da Corte entre a Câmara municipal, o governo nacional escravista crescentemente reacionário e a própria família imperial. Assim, embora os fundos de emancipação locais apenas libertassem um pequeno número de escravos, seu potencial para alimentar intensos debates políticos acerca da escravidão foi marcante. Em cada um dos dois locais, eles incitaram níveis de participação popular sem precedentes e criaram espaços de oposição local, enquanto o governo nacional continuava a resistir à abolição.

Dividido em duas partes, começamos com uma análise de como as implicações políticas dos fundos locais de emancipação mudaram ao longo da década de 1880, sempre em relação às novas posturas do governo nacional. Passamos, então, ao mundo cotidiano do processo de 'bancar' a liberdade, e exploramos as expansões nos espaços políticos que surgiram por meio destas iniciativas; prestamos atenção às constituições das campanhas locais, os rituais da emancipação e a participação de pessoas escravizadas e seus parentes, como Maria e Maria Rosa.

\section{Fundos locais de emancipação e a política nacional}

A prática de 'bancar a liberdade' foi central para o desenvolvimento do movimento abolicionista na década de 1880 . Composto de numerosos grupos que cultivavam vínculos entre si, o movimento emergiu localmente em resposta a desdobramentos da política nacional. ${ }^{15}$ Mudanças na política regional e nacional na década de 1880, entretanto, produziram diferentes significados para o uso e a relevância dos fundos locais de emancipação. Nos primeiros anos da década, os fundos eram a principal ferramenta do movimento abolicionista diante da recalcitrância do governo nacional. As mobilizações populares levaram corpos governativos locais, como a Assembleia Legislativa de Pernambuco (1883) e as câmaras municipais do Recife (1884) e Rio de Janeiro (1884) a adotar seus próprios fundos, numa tentativa relativamente conservadora de reassumir o controle sobre o pro-

15 Dentre importantes trabalhos acerca da relação entre movimentos de abrangência local e nacional no abolicionismo brasileiro, ver: Azevedo, Abolitionism, pp. 6-7, Conrad, Destruction, pp. 183-209; Robert Toplin, The Abolition of Slavery in Brazil, Nova Iorque: Atheneum, 1972, pp. 194-246; Moraes, Campanha, pp. 37-53 e 185-230. 
cesso de emancipação. Entretanto, entre a metade e o final da década, e particularmente a partir da formação do gabinete Cotegipe em agosto de 1885, ao passo que o governo nacional recrudescia sua oposição ao abolicionismo, os fundos locais de emancipação tornaram-se espaços de contestação de forma imprevista por seus fundadores.

Um esforço contrariado para estabelecer um caminho parlamentar para o fim da escravidão tornou-se catalisador de um movimento abolicionista popular. Em agosto de 1880, Joaquim Nabuco, então jovem liberal de Pernambuco, tentou introduzir um projeto na Câmara dos Deputados estabelecendo 1890 como o ano de término da escravidão. Contando com a oposição da maioria dos deputados de todo o espectro político, o projeto de Nabuco foi logo esmagado. Essa tentativa fracassada demonstrava a intransigente oposição do Parlamento à ideia de abolição e levou Nabuco a ampliar seus esforços, procurando a mudança por meio da pressão popular. Duas semanas depois, ele presidiu a formação da Sociedade Brasileira contra a Escravidão, organização vista como pioneira na consolidação das bases do movimento abolicionista nacional. Fundada em 7 de setembro de 1880, dia da Independência, a Sociedade publicou um jornal, $O$ Abolicionista, que circulou mensalmente de novembro de 1880 a dezembro de 1881. A Sociedade Brasileira Contra a Escravidão contava entre seus membros cinco deputados na legislatura então corrente, dois ex-presidentes de província, engenheiros e oficiais navais. ${ }^{16}$ Produto da elite brasileira, esses homens, todavia, deram voz a posturas políticas que os diferenciavam de seus pares sociais. ${ }^{17}$ Todos

16 Sobre o projeto de lei derrotado de Nabuco, ver: $O$ abolicionista, 1 de janeiro de 1881, p. 6. Sobre a sessão parlamentar, ver: Joaquim Aurelio Barreto Nabuco de Araujo, 24 de agosto, 1880, Annaes do Parlamento Brazileiro. Câmara dos Senhores Deputados (de agora em diante, $A C D$ ), Sessão de 1880, p. 3 (Rio de Janeiro: Typographia Imperial \& Constitucional de J. Villeneuve \& Cia., 1880), p. 336. Sobre os membros fundadores da Sociedade Brasileira, ver: Rebecca Baird Bergstresser, "The Movement for the Abolition of Slavery in Rio de Janeiro, Brazil, 1880-1889" (Tese de Doutorado, Stanford University, 1973), pp. 100-3.

17 De forma geral, concordamos com Célia Marinho Azevedo acerca das importantes diferenças entre o abolicionismo no Brasil e nos Estado Unidos. $\mathrm{O}$ argumento de que abolicionistas brasileiros compunham uma elite eurocêntrica apartada da majoritária população afrodescendente é útil para seu ponto de vista comparativo, bem como para a correção de uma tendência anterior de "canonizar" personagens abolicionistas, abordada no texto de Célia Maria Azevedo, "Quem precisa de São Nabuco?" Estudos Afro-Asiáticos, v. 23, n. 1 (2000), pp. 84-97. Ainda assim, corre-se o risco, com a generalização, de simplificar o complexo desenrolar das políticas abolicionistas no Brasil na década de 1880 , obscurecendo as principais diferenças políticas dentro da elite: as alianças e conexões entre a elite e a população geral, e em muitos casos mestiça e mulata, ainda que desiguais, e os grupos urbanos emergentes que não se adequam de maneira confortável a 
os cinco deputados perderam suas candidaturas para a re-eleição em 1881 - num outro exemplo do sentimento antiabolicionista prevalente dentro das esferas tradicionais da política brasileira.

A expansão e a vitalidade do movimento abolicionista na capital nacional dependeram do envolvimento de setores populares. A politização de jornalistas e tipógrafos, condutores ferroviários, jornalistas e estudantes das escolas militares, de medicina e engenharia ajudaram a catapultar a abolição para o cenário público. O movimento no Rio se desenvolveu num cenário urbano particularmente volátil e adotou um tom comparativamente mais combativo do que aquele que emergiu no Recife. Uma parcela dos líderes abolicionistas do Rio de Janeiro, inclusive José do Patrocínio - o impetuoso jornalista afro-brasileiro que assumiu papel central nas campanhas abolicionistas em âmbito local e nacional - participou ativamente dos levantes do vintém de 1880 , de modo que um afiado senso de protesto político informou seu ativismo abolicionista. ${ }^{18}$ A agitação popular continuou nas ruas do Rio, em outubro de 1885, com uma greve de quitandeiras que durou uma semana e foi marcada pela vociferante presença de mulheres africanas. ${ }^{19}$ A proliferação de grupos republicanos populares no início da década de 80 no Rio de Janeiro também colaborou para a criação de uma arena política pública mais carregada, uma vez que os debates em torno da abolição estavam, para muitos, entrelaçados com a ideia da derrubada da monarquia. ${ }^{20}$ As primeiras

nenhuma das categorias. Aqui estamos interessados em destacar a emergência de espaços de ação política ocupados por uma larga gama de pessoas entre membros e não membros das elites - ações que, embora nem sempre harmoniosas e uníssonas, envolviam conexões entre uns e outros. Azevedo, Abolitionism, pp. 48-80.

18 Sandra Lauderdale Graham, "The Vintem Riot and Political Culture: Rio de Janeiro, 1880", Hispanic American Historical Review, v. 60, n. 3 (1980), p. 447. Para uma abordagem do abolicionismo como um movimento complicado, plural e conflituoso, ver Wlamyra R. Albuquerque, O jogo da dissimulação: abolição e cidadania negra no Brasil, São Paulo: Companhia das Letras, 2009, p. 39.

19 Ver Juliana Barreto Farias, "Mercado em greve: protestos e organização dos trabalhadores da Praça das Marinhas, Rio de Janeiro/ século XIX", Anais do XIX Encontro Regional de História: Poder, Violência e Exclusão, ANPUH/SP-USP, São Paulo, 8-12, setembro de 2008, Cd-ROM.

20 Um estudo recente da politização dos espaços urbanos por grupos republicanos na década de 1880 no Rio de Janeiro é o de Maria Tereza Chaves de Mello, A República consentida: cultura democrática e científica do final do Império, Rio de Janeiro: ANPUH, 2007, pp. 95-106. Para uma análise profunda envolvendo raça e política popular no Rio de Janeiro no início da mesma década, ver: Thomas Holloway, "The Defiant Life and Forgotten Death of Apulco de Castro: Race, Power, and Historical Memory", Estudios Interdisciplinarios de América Latina y el Caribe, v.19, n. 1 2007), http://www1.tau.ac.il/eial/. A respeito de centros urbanos e mobilização popular em torno do republicanismo e abolicionismo, ver: June E. Hahner, Poverty and Politics: The Urban Poor in Brazil, 1870-1920, Albuquerque: University of New Mexico Press, 1986, capítulo dois. 
sociedades abolicionistas no Rio de Janeiro estabeleceram fundos de emancipação de modo a galvanizar a opinião pública, além de manumitir escravos. ${ }^{21}$

No Recife, a mobilização abolicionista local começou também por volta do momento em que Nabuco formou sua Sociedade Brasileira. ${ }^{22} \mathrm{O}$ Club Abolicionista do Recife, por exemplo, foi estabelecido por alunos da Escola de Direito em 11 de agosto de 1880, data do aniversário da fundação da instituição. Seis semanas depois, um grupo de comerciantes médios fundou a Sociedade Nova Emancipadora que, ao lado do Club Abolicionista, iniciou o desenvolvimento de um movimento abolicionista no início da década de 1880 no Recife. Certamente, estas não foram as primeiras instâncias de ativismo abolicionista na capital pernambucana. Francisco Augusto Pereira da Costa, cronista da época, observou que ao menos seis sociedades antiescravistas haviam se formado (e rapidamente se desfeito) entre 1860 e 1871 - algumas delas também organizadas por estudantes de Direito. ${ }^{23} \mathrm{O}$ poeta abolicionista Antônio de Castro Alves (1847-1871) e o futuro estadista Rui Barbosa de Oliveira (1849-1923) estavam entre os notáveis ativistas da Escola de Direito ao final dos anos 1860, sendo que suas posturas antiescravistas inspiraram as ondas de mobilização de estudantes na década de $1880 .{ }^{24}$ Em contraste com suas antecessoras, entretanto, as sociedades abolicionistas da década de 1880 imaginavam-se como integrantes de um movimento nacional mais amplo. No Recife, como no Rio de Janeiro, políticos evitavam o tema da escravidão, e o abolicionismo desenvolveu-se, assim, a partir da Escola de Direito onde “[...] um com-

${ }^{21}$ Gazeta da Tarde, 15 de janeiro de 1884, pp. 2-3; $1^{\circ}$ de fevereiro de 1884, p. 1; 23 de fevereiro de 1884, p. 3. Sobre os fundos de emancipação mais antigos, ver Conrad, Destruction, p. 177, 184.

22 Diário de Pernambuco (Recife), 21 de setembro de 1880, p. 2.

${ }^{23}$ Francisco Augusto Pereira da Costa, "A idéia abolicionista", Revista do Instituto Archeológico e Geográfico Pernambucano, n. 42 (1891), pp. 262-5.

24 A memória de Castro Alves, em particular, fez parte da produção cultural abolicionista na década de 1880. No décimo aniversário de sua morte, uma florescente sociedade literária no Rio publicou Homenagem do Gremio Litterario Castro Alves, Rio de Janeiro: Typographia Nacional, 1881. No Recife, Alfredo de Carvalho reuniu informações de contemporâneos de Alves para o seu Castro Alves em Pernambuco: recordações de um Amigo, Recife: Typographia do Jornal do Recife, 1905, pp. 4-17. Para uma visão mais completa dos anos de Alves no Recife (1862-67), ver Afrânio Peixoto, Castro Alves: o poeta e o poema, São Paulo: Companhia Editora Nacional, 1976 [1922], pp. 11-7; Lamartine Morais, Itinerário de Castro Alves no Recife, Recife: Editora Bagaço, 1997. Também, veja-se, para uma análise mais ampla da participação de Castro Alves no seu próprio contexto, Dale Graden, From Slavery to Freedom in Brazil: Bahia, 1835-1900, Albuquerque: University of New Mexico Press, 2006, pp. 83-99. 
promisso com a abolição da escravidão fazia parte do ideal do estudante de Direito brasileiro". ${ }^{25}$

\section{Os fundos locais e a questão da emancipação}

Os fundos locais de emancipação em operação no início dos anos 1880 no Rio e no Recife representavam uma crítica ao compromisso titubeante do governo nacional de acabar com a escravidão. Entretanto, tais iniciativas locais demonstravam o fraco desempenho do fundo nacional de emancipação. Mesmo assim, embora se opusesse à ideia da abolição imediata, o governo nacional não procurou reprimir os movimentos abolicionistas até 1886.

A criação de um fundo abolicionista no Recife pelo Club Abolicionista foi o primeiro indício de uma mobilização coletiva. Contando "uns 50 moços entre seus membros", o Club Abolicionista, como a Sociedade Brasileira, emergiu diretamente das elites, mas logo procurou estabelecer políticas que ampliassem a participação em suas campanhas. A princípio, o Club mirou no corpo estudantil para financiar seu fundo local de emancipação. Com as doações asseguradas num período de seis semanas, o Club Abolicionista ajudou a libertar 16 escravos em sua primeira função pública, executada enquanto o Brasil comemorava o aniversário da "Lei do Ventre Livre" de 1871, em 28 de setembro de $1880 .{ }^{26}$ Precursor da intensa politização abolicionista das escolas de Direito na década de 80, o esforço inicial do Club Abolicionista colocou uma gama de estudantes em contato com o movimento - muitos dos quais não eram originalmente de Pernambuco.

Rapidamente, o número de sociedades abolicionistas no Recife multiplicou-se de um ao final de 1880, para quatorze, em 1883, cada qual com seu fundo de emancipação. Dentre elas, dez foram criadas a partir da Escola de Direito, onde os estudantes se organizavam de acor-

25 Andrew J. Kirkendall, Class Mates: Male Student Culture and the Making of a Political Class in Nineteenth-Century Brazil, Lincoln: University of Nebraska Press, 2002, p. 144.

26 Diário de Pernambuco (Recife), 13 de agosto, 1880, p. 2. Estimamos que cerca de $10 \%$ do corpo estudantil tenha se envolvido com o Club Abolicionista. Clovis Bevilaqua publicou listas das classes de graduação da Escola de Direito do Recife; baseando-nos nesses números do início da década de 1880, calculamos uma população estudantil entre 450 e 600 pessoas, renovada anualmente. Clovis Bevilaqua, História da Faculdade do Recife, São Paulo: Instituto Nacional do Livro, 1977 [1927], pp. 118-30. 
do com sua origem regional; aqueles do Ceará, Maranhão, Sergipe, Rio Grande do Norte e Pará, por exemplo, formaram, cada qual, suas sociedades abolicionistas. Com fortes laços ligando-os à suas províncias de origem, estes grupos de estudantes engajavam-se, simultaneamente, em nível local e regional. Os estudantes paraenses, por exemplo, comandavam um fundo de emancipação no Recife, mas em 1882 também peticionaram a seu presidente provincial para abolir o tráfico de escravos interprovincial. ${ }^{27}$ Os fundos eram parte essencial de um "novo estilo político" que se desenvolvia ao longo dos anos 1880 pelo Brasil urbano, "levando a política para as ruas e praças da cidade". ${ }^{28}$ A política das ruas e praças, à sua vez, influenciou as agendas regionais e nacionais.

A consolidação do movimento no Recife e seu primeiro grande avanço ocorreram em 1883. A formação da Central Emancipadora do Município do Recife, uma federação das sociedades abolicionistas na capital da província, proporcionou em julho de 1883 uma bem-sucedida campanha pública para forçar o governo provincial a intervir na luta pela abolição criando seu próprio fundo provincial de emancipação. ${ }^{29}$ Isso significava uma notável mudança nas atitudes do governo local com relação à abolição, já que, previamente, a assembleia legislativa havia ignorado por completo a campanha antiescravista. Apesar de as 135 pessoas libertadas por meio do fundo provincial de emancipação entre 1883 e 1885 representarem uma parcela ínfima da população escravizada de Pernambuco, que girava em torno de 70.000 pessoas na metade da década, tal prática ressaltava a redução das distâncias entre a "política da rua" e a "política da legislatura". ${ }^{30}$

Os ganhos políticos no Recife foram ecoados por movimentos abolicionistas por todo o país entre 1883 e 1884 . No Rio formou-se em 1883 a Confederação Abolicionista, que unificou mais de doze sociedades abolicionistas na capital do Império. Seus vínculos com abolicionistas nacionalmente reconhecidos, como José do Patrocínio e André Rebouças, bem como com figuras internacionais como Antonio Maceo, Frederick Douglas e Victor Schoelcher, exibiram a visibilidade da Confederação. ${ }^{31}$ Ao mesmo tempo,

27 Diário de Pernambuco (Recife), 29 de setembro, 1882, p. 2.

${ }^{28}$ Lauderdale Graham, "The Vintem Riot", p. 432.

29 Jornal do Recife, 17 de julho de 1883, p. 1.

30 Conrad, Destruction, p. 292.

31 Osório Duque-Estrada, A abolição: esboço histórico, 1831-1888, intro. Rui Barbosa, Rio de Janeiro: Leite Ribeiro \& Maurillo, 1918, p. 105. 
na província do Ceará, um movimento abolicionista implacável emergiu no final da década de 1880, tendo libertado ao final de três anos 28 de 57 municipalidades. ${ }^{32}$ A noção adotada no Recife de que o governo local poderia e deveria decretar políticas para acelerar o processo de emancipação atestava a crescente influência do movimento abolicionista.

Logo depois, o crescimento do movimento popular no Rio de Janeiro impulsionou uma iniciativa semelhante da Câmara Municipal da Corte ao "tomar posição saliente no movimento emancipador" e adotar um fundo de emancipação. ${ }^{33}$ No início de 1884 , enquanto a abolição total no Ceará era celebrada com grandes festas nas ruas do Rio de Janeiro e por todo o país, a Câmara instituiu o fundo Livro de Ouro. ${ }^{34}$ Concebido pelo vereador conservador José Ferreira Nobre, o fundo tinha o propósito explícito de assegurar a "ordem" "dentro dos limites da lei”. Para tanto, Nobre invocou "o grande interesse nacional na agricultura e no comércio". ${ }^{35}$ Os vereadores não utilizavam a palavra "abolição" até 1886, e, mesmo então, divergiam significativamente a respeito dos propósitos do fundo. ${ }^{36}$ Porém, desde o início, o objetivo explícito era libertar todos os escravos no Município Neutro. ${ }^{37}$ Diferentemente

${ }^{32}$ Duque-Estrada, pp. 112-13. O livro clássico sobre o assunto é Raimundo Girão, A abolição no Ceará, Fortaleza: Editora A. Batista Fentenele, 1956.

33 José Ferreira Nobre, discurso no Livro de Ouro, AGCRJ, E:E, Book 6.1.61, 21 de janeiro de 1884 , p. 18. Para detalhes sobre o conselho, ver a introdução aos registros do conselho no AGCRJ (não publicada, sem data e sem título), escrita por Hebe Mattos e um grupo de pesquisadores, referidos como Mattos, et. al., "Livro de Ouro", pp. 7-8.

34 Sobre as celebrações no Ceará, ver a edição comemorativa da Gazeta da Tarde, 26 de abril de 1884. No Recife, as comemorações levaram mais de 2.000 pessoas às ruas. Ver Francisco Augusto Pereira da Costa, Pernambuco ao Ceará, o dia 25 de março: historico das festas celebradas em Pernambuco, Recife: Typographia Central, 1885. O Diário de Pernambuco também registrou grandes celebrações na Paraíba sobre o ocorrido no Ceará. Ver Diário de Pernambuco, 10 de abril de 1884, p. 2.

35 Ferreira Nobre, fala no Livro de Ouro, Boletim da Ilusstrissima Camara Municipal da Corte, Rio de Janeiro: Typ. Imperial e Constitucional de J. Villeneuve \& C.; (henceforth Boletim), 1 de maio de 1884 , p. 49

${ }^{36}$ O presidente do Conselho, João Pereira Lopes, referiu-se pela primeira vez à "abolição da escravidão" na cerimônia de emancipação de 14 de março de 1886. Boletim, 18 de março de 1886, p. 122.

37 Discurso, José Ferreira Nobre, AGCRJ, E:E, Book 6.1.61, 21 de janeiro de 1884, p. 19. Várias propostas para o fim da escravidão na cidade foram feitas subsequentemente. Em julho de 1885, por exemplo, o conselheiro visconde de Santa Cruz propôs uma loteria municipal por meio da qual a escravidão seria exterminada em 18 meses. Tais ideias foram mais tarde rejeitadas pelo ministério do Império, a quem o conselho estava subordinado. Visconde de Santa Cruz, speech, Boletim, 25 de julho de 1885, p. 30; Relatorio apresentado à Assembleia Geral Legislativa na primeira sessão da vigesima legislatura pelo Ministro e Secretario do Estado dos Negocios do Imperio, Barão de Mamoré, Rio de Janeiro: Imprensa Nacional, 1886, p. 23; Boletim, 15 de abril 1886 p. 34. 
do que ocorreu no Recife, o movimento abolicionista não pressionou diretamente pela criação do Livro de Ouro. O Livro não era o foco dos abolicionistas que, ao discuti-lo, oscilavam entre o elogio e o desdém, ao sabor das circunstâncias. Ainda assim, a Confederação Abolicionista e a Câmara colaboraram entre si no 'bancamento' da liberdade. ${ }^{38}$ Num contexto político acalorado que se tornava crescentemente polarizado em torno da questão da abolição, era difícil para a Câmara e seu fundo permanecerem neutros. Divididos e instintivamente conservadores, os vereadores ainda assim tornaram-se partícipes significativos dos debates acerca da abolição. ${ }^{39}$ Para complicar a situação mais ainda, os vereadores forjaram laços entre o Livro e a família imperial. O imperador assinou a primeira página do livro comemorativo que levava seu nome, e acompanhou as cerimônias de emancipação ao lado de sua esposa e sua filha, a herdeira do trono, Isabel. O Fundo, assim, tornou-se um foco de tensões entre a Câmara, os movimentos abolicionistas locais, a monarquia e o governo nacional no coração político do Império.

\section{Os fundos locais ante a virada escravista no parlamento}

Criado em maio de 1884, o Livro surgiu num momento de aparente

${ }^{38}$ O conselho permitiu que a Confederação utilizasse edifícios municipais para seus encontros em 1883, mas em 1887 o mesmo conselho recusou-se a repetir a prática, gerando indignação. O conselho também impediu propagandas abolicionistas nas ruas em 1884, instigando a $\mathrm{Ga}$ zeta da Tarde a denunciar o Livro de Ouro como "uma mentira", algo feito simplesmente "para inglês ver". João Clapp para o Conselho Municipal, AGCRJ, E:E Book 6.1.41, Rio de Janeiro, 22 de junho de 1883, p. 6; Boletim, 22 de dezembro de 1887, p. 91; "A Municipalidade e a Abolição", Gazeta da Tarde, 2 de maio de 1884, p. 1. Uma contenda pessoal entre Patrocínio e Nobre tem também repercussão. Em 1886, Patrocínio denunciou Nobre, advogado, por defender proprietários de escravos em juízo mesmo enquanto presidia o Livro de Ouro. No mesmo ano, Nobre tentou barrar a vitória eleitoral de Patrocínio. Gazeta da Tarde, 13 de outubro e 8 a 24 de novembro de 1886 .

39 A história do governo municipal do Rio tem sido negligenciada por historiadores, e muito permanece por ser descoberto acerca das carreiras dos conselheiros municipais na cidade no século XIX. O recente estudo de Juliana Teixeira de Souza contraria essa tendência, debruçando-se principalmente sobre o papel do conselho no controle do fornecimento e distribuição de alimentos na Corte: "A autoridade municipal na corte imperial: enfrentamentos e negociações na regulação do comércio de gêneros (1840-1889)" (Tese de Doutorado, Unicamp, 2007). Hebe Mattos et. al. concluíram que, embora o conselho tradicionalmente houvesse sido dominado pelas elites cafeeiras, com a reforma eleitoral de 1881 os conselheiros passam a surgir, largamente, também entre profissionais liberais, influenciando-se assim a tomada de decisões competentes àquele foro. Mattos, et.al., "Livro de Ouro", p. 3, 10. Os candidatos a postos no conselho em 1886 incluíam um farmacêutico, um médico e o dono de uma chapelaria. Gazeta da Tarde, 25 de junho de 1886, p. 3; 30 de junho de 1886, p. 3. Muitos conselheiros eram proprietários de escravos, gradualmente libertados como parte dos esforços dos novos conselheiros. 
otimismo para o abolicionismo. A província do Amazonas logo seguiria o Ceará na abolição da escravidão, e em junho de 1884 um ministério reformista liderado pelo senador liberal Manoel Pinto de Souza Dantas assumiu o poder endossando um projeto de lei, chocante para muitos, que contemplava um processo de libertação não ancorado no princípio da indenização. Dito projeto focava especificamente na população escrava acima de sessenta anos, mas mesmo assim, somente a ideia de libertar sem alguma forma de compensação provocou uma crise parlamentar. Dentro de um ano, Dantas foi substituído por outro liberal, José Antonio Saraiva. ${ }^{40}$ Saraiva diferia enormemente de Dantas, advogando menos envolvimento do governo com a abolição e rejeitando o plano de manumissão (limitada) sem indenização. Enquanto o impasse acerca do projeto de lei de manumissão prosseguia, o imperador chamou o senador conservador baiano João Maurício Wanderley, o Barão de Cotegipe, para formar o que seria um gabinete firmemente antiescravista. Cotegipe supervisionou a aprovação da Lei dos Sexagenários em setembro de 1885, tendo ela assumido um caráter que em seus termos e espírito pouco remetia ao intento do projeto original de Dantas. ${ }^{41} \mathrm{O}$ resultado final enfureceu os abolicionistas, especialmente no Rio de Janeiro, que chamaram a lei de "um projeto monstruoso", ${ }^{42}$

As frustrações dos abolicionistas com o novo contexto político transformaram os significados dos fundos de emancipação. Em julho de 1885, um vereador municipal, Fernando Francisco da Costa Ferraz, à luz da evolução reacionária da Lei dos Sexagenários, disse o seguinte sobre o Livro:

Se pelo lado do pequeno numero das manumissões dadas pela Illma. camara [sic] pode parecer insignificante o seu exito, elle [sic] cresce de importancia e de significação, porque exprime por parte da primeira municipalidade do Imperio, um protesto em nome da civilisação [sic] e da liberdade contra um regimen $[s i c]$ de oppressão [sic] e de opprobrio [sic] ${ }^{43}$

40 Duque-Estrada, Abolição, 135.

${ }^{41}$ A lei apenas libertava imediatamente os escravos com idade maior ou igual a 65 anos, e ainda impunha severas penalidades àqueles que abrigassem escravos fugitivos. A análise mais recente e detalhada da Lei dos Sexagenários, de 1885, é a de Joseli Maria Nunes Mendonça, Entre a mão e os anéis: a lei dos sexagenários e os caminhos da abolição no Brasil, Campinas: Editora da Unicamp, 1999.

${ }^{42}$ Gazeta da Tarde, 28 de setembro de 1885, p. 1.

43 Dr. Fernando Francisco da Costa Ferraz, "Exposição", Boletim, 25 de julho de 1885, p. 27. A 
Conquanto tenha sido criada como uma medida conservadora, durante a era Cotegipe (agosto de 1885 - março de 1888), o Livro tornou-se então emblemático da resistência política local no coração da nação.

Após a passagem da Lei dos Sexagenários, Cotegipe continuou a reverter os ganhos anteriores dos abolicionistas. Começou com as eleições para a Câmara de Deputados em janeiro de 1886, as quais removeram todos os políticos abolicionistas do parlamento - inclusive Joaquim Nabuco e José Mariano, do Recife. Continuando, em junho de 1886, o gabinete Cotegipe aprovou uma série de regulamentações regressivas para a Lei dos Sexagenários, apelidadas pelos abolicionistas de "regulamento negro". Fundamentalmente, o "regulamento negro" reabriu o tráfico de escravos entre a capital imperial e a província circundante do Rio de Janeiro após a Lei dos Sexagenários ter banido o comércio interno de escravos - expondo, potencialmente, os cerca de 30.000 escravos ainda residindo na Corte à venda para as plantations cafeicultoras. ${ }^{44}$ Também permitiu que escravos entrassem na cidade, solapando as intenções da Câmara de livrar a Corte da escravidão. ${ }^{45} \mathrm{Em}$ meio de uma reavivada campanha abolicionista no Rio de Janeiro contra o regulamento, José do Patrocínio lançou uma campanha política em nível municipal para combater as políticas escravistas do ministério Cotegipe. Vitorioso, Patrocínio foi eleito vereador em $1886 .{ }^{46}$

Neste contexto do regulamento e das eleições parlamentares, as atividades relacionadas ao Livro de Ouro realmente contrastavam com a posição do gabinete de Cotegipe. Estas provocariam duradouras tensões entre a Câmara Municipal e o Gabinete Imperial a que estava subordinado. Na cerimônia de emancipação de 29 de julho de 1886, por exemplo, em frente ao imperador e à reunião dos dignitários do gabinete Cotegipe, o presidente da Câmara, João Pereira Lopes, fez um inflamado discurso. Argumentando que "como não póde [sic], esta Illma.

resistência do Conselho Municipal do Rio à subordinação ao ministério do Império lhe fizera experimentar uma pequena, porém persistente, estocada por parte dos gabinetes imperiais, uma vez que desde o Ato Adicional de 1834 os conselhos das capitais foram despidos de seus poderes anteriores. Ver Richard Graham, Patronage, p. 48, 86.

${ }^{4}$ Sobre a repercussão da Lei dos Sexagenários e das "Black Regulations" no Rio ver Conrad, Destruction, pp. 230-37.

45 Um mês antes, conselheiros haviam votado pela taxação de quaisquer escravos que adentrassem a municipalidade, bem como pela deliberação de apenas libertar aqueles que tivessem sido registrados antes de 1886. Boletim, 1 de abril de 1886, pp. 15-16.

46 Sobra a campanha, ver Gazeta da Tarde, 19 de junho - 5 de julho de 1886. 
camara [sic] ser indifferente [sic] á [sic] vontade de seu soberano quando elle [sic] mostra desejos que estão em harmonia com os de seu povo", disse que a Câmara demandava liberdade, um "direito sagrado e inalienável" que havia sido "roubado" aos escravos. ${ }^{47}$ Assinalou também que "o regulamento de 12 de Junho, que manda annexar [sic] a côrte [sic] á [sic] provincia [sic] do Rio de Janeiro", iria "retardar a abolição e conseguintemente o progresso do paiz [sic]", apelando diretamente ao imperador para revogá-la. ${ }^{48}$ Também, na cerimônia de 7 de setembro (dia da Independência), enquanto Nabuco e outros faziam campanha em âmbito nacional para chamar atenção aos recentes e terríveis castigos aplicados a quatro escravos em Paraíba do Sul (dois dos quais haviam morrido), Lopes uniu sua voz à condenação geral e disse ao imperador: "Vosso pai proclamou a independencia [sic] e vós [sic] proclamareis [sic] a extincção [sic] da escravidão". ${ }^{49}$ Embora oradores subsequentes e anteriores tenham se atido a uma linguagem mais conservadora nas cerimônias, a evolução geral da posição política da Câmara acerca do Livro de Ouro atiçou as chamas do abolicionismo. ${ }^{50}$

Tanto no Recife quanto no Rio de Janeiro, enquanto o governo nacional resistia à abolição durante a década de 1880, fundos locais de emancipação - mesmo quando pretendidos moderados ou conservadores - tornaram-se espaços visíveis e ativos de oposição política abolicionista. O "bancamento da liberdade" tornou-se uma arma dentro de disputas de poder entre governos locais e parlamentares, o movimento abolicionista popular e a monarquia. $\mathrm{O}$ trecho seguinte explorará algumas das práticas locais e cotidianas de "bancar" a liberdade, e suas implicações na popularização da política.

\section{Práticas e implicações do "bancamento" da liberdade}

Por volta de março de 1883, os diversos fundos de emancipação no Recife haviam libertado cerca de 500 escravos - o que representava cerca de

47 Sobre as evidências prévias dessas tensões acerca de vários temas, ver Boletim, 6 de maio de 1886, p. 88.

48 Discurso, Pereira Lopes, Boletim, 5 de agosto de 1886, pp. 39-41.

49 Discurso, Pereira Lopes, Boletim, 16 de setembro de 1886, p. 92 . O chicote foi oficialmente abolido em outubro de 1886 .

50 Ver especialmente o discurso do presidente interino, dr. Carlos Cláudio da Silva, na terceira cerimônia em dezembro de 1885. Boletim, 5 de dezembro de 1885, pp. 17-132 (os números das páginas refletem a numeração errática do documento original). 
4\% das 11.544 pessoas escravizada da municipalidade. ${ }^{51} \mathrm{O}$ fundo do Livro de Ouro do Rio de Janeiro libertou 797 escravos numa série de nove cerimônias de emancipação realizadas entre 1885 e 1887. Esses números representam apenas $3 \%$ da diminuição na população escravizada da cidade entre 1884 e 1887 na população escravizada da cidade. Esta diminuição foi a consequência de mortalidade, manumissão e a prática continuada de venda ou transferência de escravos para fora do Município Neutro. ${ }^{52}$ Os fundos, assim, não acarretaram uma diminuição significativa da população escravizada em nenhuma das duas cidades.

Ainda assim, o processo de bancamento da liberdade forjou novos vínculos entre o abolicionismo e a popularização da política. Mulheres escravizadas foram participantes centrais desse processo. Os fundos eram explicitamente concebidos para priorizar a libertação de mulheres, especialmente aquelas mais novas e com filhos. ${ }^{53}$ Os criadores do fundo não ofereciam explicações, como se as razões fossem óbvias. Libertar mulheres escravizadas reforçava a moral paternalista e, mais importante, continuava a "lógica do ventre livre" que há tempos formava a base dos projetos emancipacionistas no Brasil, inclusive da Lei de $1871 .^{54}$

51 A respeito dos escravos libertos por fundos particulares de emancipação no Recife ver: Castilho, “Abolitionism Matters", p. 266. A respeito da população escrava em Pernambuco, ver: Falla com que o Exm. Sr. Conselheiro Francisco Maria Sodre Pereira abrio no $1^{\circ}$ de Março de 1883 a Assembléa Legislativa Provincial de Pernambuco, Recife: Typografia de Manoel Figueiroa e Filhos, 1883, pp. 73-4.

52 Dos 797 escravos libertados por meio do Fundo, 766 foram libertados com compensações e apenas $31 \mathrm{sem}$ qualquer tipo de ressarcimento. Acerca dos escravos libertados em cada uma das nove cerimônias de emancipação, ver: Boletim, 29 de julho de 1885, p. 29; Boletim, 10 de setembro de 1885, pp. 115-7; Gazeta de Notícias, 2 de dezembro de 1885, p. 1; Boletim, 18 de março de 1886, p. 122; AGCRJ, E:E, Book 6.1.61, 29 de julho de 1886, p. 74; Boletim, 16 de setembro de 1886, pp. 89-93; Gazeta de Notícias, 3 de dezembro de 1886, p. 2; AGCRJ, E:E, Book 6.1.41, 7 de setembro de 1887, p. 44; Boletim, 2 de dezembro de 1887, p. 69. A população escrava do Rio diminuiu drasticamente entre 1884 e 1887 - quando passou de 24.615 a 7.488 indivíduos. Essa redução deve-se, em parte, aos resultados do "Regulamento Negro" de 1886. Conrad, Destruction, p. 285.

53 Sobre o fundo do Club Abolicionista ver: Diário de Pernambuco, 18 de setembro de 1880, p. 4. Sobre o fundo do Livro de Ouro do Rio de Janeiro, ver: "Regulamento substitutivo para o Livro de Ouro", Boletim, 10 de julho de 1885, p. 26. Informações sobre outros fundos locais de emancipação (ver nota 9) sugerem que neles as mulheres eram priorizadas de forma muito mais enfática do que nos fundos aqui discutidos.

${ }^{54}$ Para uma visão mais detida das ideias em torno do "ventre livre" na escravidão brasileira ver: Cowling, "Debating Womanhood, Defining Freedom", pp. 287-88. Sobre os precedentes históricos para a ideia do "ventre livre" ver: Conrad, Destruction, p. 90. Uma sofisticada análise da questão do "ventre livre" na lei e na jurisprudência está em: Eduardo Spiller Pena, Pajens da Casa Imperial: jurisconsultos, escravidão e a lei de 1871, Campinas: Editora Unicamp, 2001. A respeito da prioridade dada a mulheres escravizadas com filhos pela lei de 1871 e pelo fundo nacional de emancipação, ver: Dauwe, "A libertação gradual”, pp. 76-7, 82, 100-1, 108. 


\section{A política do ritual}

O ritual público desempenhou um papel fundamental na operação dos fundos de emancipação. As elaboradas cerimônias de emancipação encenadas nas cidades por vezes reforçavam o gradualismo e a "ordem", e, por outras, contestavam as hierarquias sociais e políticas. Alcançando tanto a elite quanto os espaços cotidianos da vida urbana, os rituais incorporavam o ativismo político e a dimensão de espetáculo público do abolicionismo brasileiro. ${ }^{55}$

De 1880 em diante, O Club Abolicionista e a Sociedade Nova Emancipadora, no Recife, organizaram noites de pompa para celebrar as conquistas de seus respectivos fundos. Estes eventos de gala contavam com performances teatrais e musicais, culminando com a distribuição de cartas de liberdade para escravos. ${ }^{56}$ Com o tempo, as cerimônias cresceram, assim como o número de escravos libertados. Se na primeira cerimônia de emancipação, em 1880, 16 escravos haviam sido libertados, em setembro de 1883 centenas de pessoas se reuniram no Teatro Santa Isabel para desfrutar das festividades e da libertação de 200 escravos. ${ }^{57}$ O governo provincial de Pernambuco também assumiu um papel cerimonial mais amplo ao longo do tempo, de modo que, em 1883, um juiz municipal distribuiu os certificados de liberdade. Esse uso do ritual público, sendo o governo agora retratado como protagonista, tinha por objetivo reforçar uma maneira "propriamente" gradual e ordeira de extinção da escravidão, preservando a ideia de uma liberdade generosamente concedida, e não ganha ou conquistada. ${ }^{58}$

Entretanto, o fato de que os eventos comemorativos dos fundos de emancipação começaram a se organizar em torno do aniversário da "Lei do Ventre Livre" de 1871, gerava desafios para a agenda do governo parlamentar. ${ }^{59}$ Ao preparar atividades para um dia em que o governo

${ }^{55} \mathrm{O}$ abolicionismo brasileiro remetia "o dinamismo das campanhas anglo-americanas de antiescravismo", que envolvia "propaganda para as massas, petições, reuniões públicas, processos judiciais e boicotes, apresentando a ação antiescravista como um imperativo moral e político". Seymour Drescher, "Brazilian Abolition in Comparative Perspective", Hispanic American Historical Review, v. 68, n. 3 (1988), pp. 429-60.

56 Jornal do Recife, 30 de setembro de 1881, p. 2.

57 Jornal do Recife, 17 de setembro de 1883, p. 1; e 26 de setembro de 1881, p. 1.

58 A respeito das estratégias da elite para a preservação dos privilégios senhoriais por meio do controle do processo de abolição - literalmente buscando preservar a palavra "senhor" - ver: Albuquerque, $O$ jogo da dissimulação, pp. 113-26.

59 Diário de Pernambuco, 13 de agosto de 1880, p. 2; "Sessão Preparatória de Instalação", 
pretendia comemorar seus próprios esforços de emancipação, as sociedades abolicionistas construíram um "discurso contestatório usando o discurso oficial", da mesma forma que fizeram outros movimentos sociais oitocentistas pela América Latina. ${ }^{60}$ Em agosto de 1882, enquanto o Club Abolicionista do Recife comemorava seu segundo aniversário, se publicou uma carta aberta ao primeiro ministro pressionando o governo a focar suas atenções na abolição. A carta trazia uma avaliação da efetividade de iniciativas locais em comparação com os esforços do governo nacional: "Temos alforriado perto de cem escravos até agora. Tem se gastado \$600, \$800 e até 1:000 com cada escravo; este quadro é eloquente, compare-o com o da Junta de Emancipação". ${ }^{11}$ Os rituais anuais enfatizavam essa postura crítica.

Se a crítica vinda das províncias era vigorosa, seu impacto era ainda mais difícil de ser ignorado na capital nacional. As pródigas cerimônias de emancipação do Livro de Ouro tornaram-se um símbolo poderoso, e público, do antiescravismo na Corte. Realizadas no Paço Municipal, em dias de aniversários de membros da família imperial e nos aniversários da Independência do Brasil, as cerimônias desempenhavam a tripla função de promover a abolição, a Câmara e a monarquia. ${ }^{62}$ Os rituais

Memorandum, IAHGP, Coleção da Sociedade Nova Emancipadora (henceforth CSNE), 26 de setembro de 1880 .

${ }^{60}$ Nils Jacobsen e Cristóbal Aljovín de Losada, "The Long and Short of It: A Pragmatic Perspective on Political Cultures, Especially for the Modern History of the Andes", in Nils Jacobsen e Cristóbal Aljovín de Losada (orgs.), Political Cultures in the Andes, 1750-1950 (Durham: Duke University Press, 2005), p. 9

${ }^{61}$ Jornal do Recife, 11 de agosto de 1882, p. 2. Este último foi publicado em agosto de modo a coincidir com o aniversário da escola de Direito. Foi assinado pelo presidente, Dr. Joaquim de Barros Sobrinho, e o primeiro e o segundo secretários, Joaquim Felipe da Costa e Carizio de Barros.

${ }^{62}$ As cerimônias foram realizadas em 29 de julho, 7 de setembro, e 2 de dezembro de $1885 ; 14$ de março, 29 de julho, 7 de setembro e 7 de dezembro de 1886; 7 de setembro e 2 de dezembro de 1887. As cerimônias de 29 de julho, 2 de dezembro e 14 de março foram realizadas nos dias do aniversário de Isabel, Pedro e Teresa Cristina, respectivamente. Para saber mais sobre o programa de uma das cerimônias, ver: "Programa da festa municipal pelos donativos do Livro de Ouro", Boletim, 28 de julho de 1885, p. 55. Sobre os dias nacionais de festividade e sua relação com a monarquia, ver: Robert Daibert Júnior, Isabel: a Redentora dos escravos. Uma história da Princesa entre olhares negros e brancos (1846-1980), Bauru, São Paulo: Editora da Universidade do Sagrado Coração, 2004, pp. 41-7, 58. A respeito da compreensão popular e das elites em torno das festividades na Bahia, num período anterior, ver: Hendrik Kraay, "Definindo nação e estado: rituais cívicos na Bahia pós-Independência", Topoi, n. 3 (2001), pp. 64-90. Ainda, a respeito da maneira como os rituais públicos sustentavam o poder monárquico no Brasil Imperial, ver: Lilia Moritz Schwartz, As barbas do imperador: D. Pedro II, um monarca nos trópicos, São Paulo: Companhia das Letras, 1998, capítulo 10. 
tornaram-se "um fato político repetitivo que comprometia a própria Coroa. No acelerado clima político da época, repetitivos e solenes atos públicos pró-libertação dos escravos com a presença da família imperial, tinham seu peso político próprio". ${ }^{63}$ Um retrato comemorativo da primeira cerimônia de 1885, encomendado pela Câmara e orçado em 10 contos de réis - quantia que teria sido suficiente para bancar outra cerimônia de emancipação - demonstrava a expectativa de que a importância do ritual fosse venerada na cidade muito depois de a multidão ter se dispersado. ${ }^{64}$ Ainda assim, caricaturas das cerimônias, zombando de vereadores e da família imperial, apareciam regularmente no irreverente jornal Revista Illustrada, contestando a própria representação e a memória pública da "invenção da tradição" dos rituais. ${ }^{65}$

Como qualquer ato político, tais rituais geravam controvérsias. As cerimônias municipais no Rio de Janeiro, durante os anos finais de 1880, expuseram as amplas brechas abertas entre a Câmara municipal, a família imperial e o gabinete Cotegipe no que dizia respeito à escravidão. ${ }^{66}$ A Câmara e o ministro do Império de Cotegipe, Ambrósio Leitão da Cunha, Barão de Mamoré, se enfrentaram por causa do Livro de Ouro em 1886. A família imperial, embora de acordo com as posições do ministério, procurou evitar um confronto público. ${ }^{67}$ Entretanto, a

${ }_{63}$ Mattos, et. al., "Livro de Ouro", p. 13.

64 "Termo de contrato entre a Illma. Camara e Pedro José Pinto Peres para a pintura de uma tela comemorativa", AGCRJ, E:E, Book 6.1.42, 3 de setembro de 1885, pp. 17-8. Para comentários, ver: Gazeta da Tarde, 14 de julho de 1886, p. 2; uma reprodução da imagem pode ser vista em: Daibert Júnior, Isabel, p. vi.

${ }^{65}$ A sociedade brasileira passava por importantes e rápidas mudanças nesse momento, da urbanização e imigração ao fim da escravidão, anunciado pela Lei do Ventre Livre de 1871. De fato, "o impacto que a extinção da escravidão causou numa sociedade construída sobre a legitimidade da propriedade de pessoas não pode ser expressa em números", Albuquerque, $O$ jogo da dissimulação, p. 97. Seguindo a sugestão de Eric Hobsbawm de que rituais e tradições são comumente inventadas precisamente para criar um sentido de continuidade histórica em momentos de mudança econômica e social rápida, deveríamos, talvez, não nos surpreender com a tentativa do Conselho de "inventar" rituais, evocando as instituições monárquicas e ocupando dias de festividade nacional. Ver: Eric Hosbawm, "Inventing Traditions", in Eric Hobsbawm e Terence Ranger (orgs.), The Invention of Tradition (Nova York: Cambridge University Press, 1983), pp. 4-5, 8. Para consultar imagens que satirizam as cerimônias: $A$ Revista Illustrada, 12 de setembro de 1885, p. 6.

${ }^{66}$ Cerimônias locais de emancipação também levaram a contestações políticas no Recife. Senespleda Battaglia, uma cantora italiana de opera, desafiou as ordens de sua trupe e seu diretor, bem como os desejos expressos da assembleia provincial de Pernambuco quando, em 1881, apareceu publicamente numa cerimônia de manumissão. Ver: Ferreira et. al., Suaves Amazonas, p. 54.

${ }^{67}$ Ao interpretar a atitude do imperador e da família imperial, recorremos ao que Sidney Chalhoub chama de "arte de bordejar", ou ziguezaguear politicamente, utilizada pelo imperador no processo 
importância do papel público da família imperial nas cerimônias do Livro de Ouro - cujos olhares e palavras eram todos comentados pela imprensa - não era ignorada por ninguém. ${ }^{68}$

Em abril de 1886, a Câmara pediu à princesa Isabel que liderasse uma "comissão de senhoras" para angariar fundos para o Livro de Ouro. ${ }^{69}$ O conde D'Eu, marido da princesa, consultou Mamoré, e este lhe respondeu bruscamente que "o Gabinete não recomendava que Sua Alteza, a Imperial Princesa, emprestasse o grande prestígio de sua posição" às iniciativas da Câmara, aconselhando ainda "que ela mantenha a neutralidade". Disse Mamoré que as iniciativas da Câmara "ultrapassam seu mandato e não podem ser aprovadas pelo Governo", uma vez que alegadamente excediam os limites da Lei dos Sexagenários de 1885 . $^{70}$ A princesa e o conde D'Eu cederam às preocupações de Mamoré naquela ocasião. O historiador Roderick Barman, examinando esse intercâmbio, concluiu que Isabel e seu marido "não desempenharam papéis nesse enredo [a radicalização do abolicionismo] que dominou os interesses públicos em 1886". ${ }^{71}$ A atenção ao "bancamento da liberdade", entretanto, possibilita outra interpretação. A participação de Isabel na distribuição pública das manumissões nas cerimônias do Livro de Ouro revela que a princesa, deliberada e visivelmente, associara-se às causas abolicionistas desde 1885, continuando a fazê-lo, a despeito dos expressos desejos dos ministros imperiais, ao longo de $1887 .{ }^{72}$

de elaboração da Lei do Ventre Livre de 1871. O imperador e Isabel certamente tornaram-se mais abertamente pró-abolicionistas ao longo da década de 1880, mas o termo é ainda útil para esta década, uma vez que expressa a tentativa de manter o distanciamento e a neutralidade vistos como apropriados para uma instituição política como a monarquia, enfurecendo tanto abolicionistas quanto escravocratas. Ver: Chalhoub, Machado de Assis, pp.139-55. Sobre o apoio do imperador à abolição, ver: José Murilo de Carvalho, Teatro de sombras: a política imperial, Rio de Janeiro: Civilização Brasileira, 2007, capítulo 2.

68 Por exemplo, "Dous de Dezembro", Gazeta de Notícias, 3 de dezembro de 1886, p. 2; "Prosigam!", Gazeta da Tarde, 30 de julho de 1886, p. 1; A Revista Illustrada, 8 de janeiro de 1887 , p. 3, 6.

${ }^{69}$ Boletim, 15 de abril de 1886, p. 28.

${ }^{70}$ Gaston, Conde d'Eu, para Ambrósio Leitão da Cunha, Barão de Mamoré, Rio de Janeiro, 7 de abril de 1886, AHMIP, 1.DLC-7.4.886, Orl.C.1-18; Mamoré para Conde d'Eu, Rio de Janeiro, 9 de abril de 1886, AHMIP, M.196, 8885.

71 Roderick J. Barman, Princess Isabel of Brazil: Gender and Power in the Nineteenth Century, Wilmington, Delaware: Scholarly Resources Inc., 2002, p. 175. Barman empreende uma interessante análise de gênero dessa e de outras trocas, nas quais políticos se alinhavam a Isabel, herdeira do trono, a favor de seu marido.

72 Alega-se que Isabel também tenha feito uma grande contribuição financeira à cerimônia de março de 1886. "Chronica do Bem", Gazeta da Tarde, 13 de março de 1886, p. 1. 
Ministros, enfurecidos com a frequência pública da família imperial nas cerimônias de emancipação, em que vereadores faziam estridentes discursos contra a escravidão, logo tramaram uma vingança apropriadamente pública. ${ }^{73}$ Ditava o protocolo que a família imperial fosse acompanhada às cerimônias por um cortejo de dignitários incluindo, crucialmente, os ministros do Império e da Agricultura. ${ }^{74}$ Após o protesto declarado de Pereira Lopes contra o "regulamento negro" na cerimônia de julho de 1886, Mamoré deixou de comparecer à cerimônia seguinte no dia da Independência, em 7 de setembro de 1886. Em dezembro daquele ano, ao aniversário de d. Pedro II, nenhum de seus ministros compareceu. Os jornais republicanos alegremente mexericaram essas humilhações públicas ao monarca, utilizando os episódios para criticar tanto a recusa intransigente do ministério em ceder às pressões abolicionistas, quanto a frágil posição do próprio imperador. ${ }^{75}$

Os rituais eram políticos ainda em outros sentidos. $\mathrm{O}$ ato de fazer uma pessoa escravizada ajoelhar-se e receber uma carta de liberdade, ressoando o imaginário das sociedades abolicionistas através do Atlântico, reforçava e ao mesmo tempo contestava as hierarquias sociais estabelecidas. ${ }^{76}$ Eram rituais que envolviam a representação pública de laços de patronato e clientela, e também a promessa simbólica de um futuro de obediência, por parte dos escravos, e benevolência, por parte

73 A Gazeta da Tarde descrevia as cerimônias como "abolicionistas" a partir de 1886, e saudava o presidente do conselho no mesmo ano, Dr. João Pereira Lopes, por suas ações pela causa abolicionista. Gazeta da Tarde, 23 de setembro de 1886, p. 1; "A Regência e o ministro", Gazeta da Tarde, 12 de agosto de 1887, p. 1.

74 Estes dignitários estavam presentes nas cerimônias até 29 de julho de 1886. Gazeta da Tarde, 2 de dezembro de 1885, p. 2; Boletim, 18 de março de1886, p. 122; Boletim, 5 de agosto de 1886, p. 43.

75 "Sete de Setembro", Gazeta da Tarde, 7 de setembro de 1886, p. 1; "Libertação da Corte", O Paiz, 3 de dezembro de 1886, p. 1; "Semana Politica", Gazeta da Tarde, 4 de dezembro de 1886, p. 1; "Chronica", A Revista Illustrada, 18 de dezembro de 1886, p. 2. Os ministros retornaram para a cerimônia seguinte em setembro de 1887. Gazeta da Tarde, 7 de setembro de 1887, p. 2.

76 A imagem de escravos ajoelhados popularizou-se por meio da descrição de Wedgewood na década de 1780, utilizada pelas campanhas britânicas contra o comércio negreiro e, mais tarde, empregada em campanhas antiescravistas na América do Norte. Claire Midgeley, Women Against Slavery: The British Campaigns, 1780-1870, Londres: Routledge, 1992, pp. 37-8; 97-100. Décadas mais tarde, a Sociedade Abolicionista Espanhola especificou que "o emblema da Sociedade é a um homem negro com um joelho no solo, suas mãos envolvidas por uma corrente, numa atitude suplicante". Sociedad Abolicionista Española, Sesión del 23 de Enero de 1881, Madrid: Imprenta de A. J. Alaria, 1881, p. 2. Sobre a Sociedade ver: Christopher Schmidt-Nowara, Empire and Anti-Slavery: Spain, Cuba and Puerto Rico, 1833-1874, Pittsburgh: Pittsburgh University Press, 1999. 
daqueles que os libertavam, uma vez que as elites há muito se inquietavam com o temor da violência e da vadiagem que, acreditavam, seguiriam a abolição. ${ }^{77}$ Tal ato assemelhava-se a cerimônias promovidas pelo fundo nacional de emancipação, com uma diferença vital: nas cerimônias do fundo nacional de emancipação, os donos dos escravos lhes entregavam os certificados. ${ }^{78}$ Os fundos locais substituíam proprietários de escravos por outras figuras de autoridade, externas à relação senhor - escravo - a princesa Isabel, juízes locais, e, por vezes, os próprios abolicionistas distribuíam cerificados, ao mesmo tempo desempenhando o heroísmo benevolente que acreditavam possuir e ressignificando um ritual "oficial" como "contestatório" ao remover os proprietários dos escravos da cena.

Assim, embora que o discurso da gratidão fosse ainda fortemente reafirmado nas cerimônias dos fundos locais, o centro destas moveu-se das relações senhor - escravo para laços sociais de patronato mais amplos. Dessa forma, confirmaram-se publicamente as desconfortáveis consequências políticas da "Lei do Ventre Livre" de 1871 para os proprietários de escravos: o crescente poder de indivíduos e do estado para intervir naquilo que os proprietários compreendiam como uma relação puramente privada com seus escravos. ${ }^{79}$ Os escravos, é claro, havia muito apelavam ao estado e a aliados individuais em suas lutas contra seus proprietários, e agora o faziam com frequência crescente. ${ }^{80}$ Maria Rosa, no Rio de Janeiro, seguiu uma tradição de escravos que buscavam o patronato monárquico. Apelos como os seus acirravam as tensões entre

77 Para um dos conselheiros na Corte, "Em lugar de conquistadores e conquistados, a história recordará os benevolentes e os beneficiários", "Exposição lida pelo Dr. F. F. da Costa Ferraz", Boletim, 10 de setembro de 1885, pp. 115-17.

78 Dauwe, "A libertação gradual", pp. 95-100.

${ }^{79}$ Chalhoub, Machado de Assis, pp. 226-27.

${ }^{80}$ Sobre litígios envolvendo escravos ao longo do seculo XIX, ver: Keila Grinberg, Liberata: a lei da ambiguidade. As acões de liberdade da Corte de Apelação do Rio de Janeiro no século XIX, Rio de Janeiro: Relume Dumará, 1994, pp. 24-8. Sobre a transição das práticas de apelação de escravos a figuras monárquicas, ver: Russell-Wood, A.J.R, “'Acts of Grace’: Portuguese Monarchs and Their Subjects of African Descent in Eighteenth-Century Brazil", Journal of Latin American Studies, v. 32, n. 2 (2000), pp. 307-32; Kirsten Schultz, Tropical Versailles: Empire, Monarchy and the Portuguese Royal Court in Rio de Janeiro, 18081821, Nova York: Routledge, 2001, pp. 165-76; Mary Karasch, Slave Life in Rio de Janeiro, 1808-1850, Princeton: Princeton University Press, 1987, pp. 339-41. A respeito do crescente recurso da população escrava à polícia nas décadas de 1870 e 1880, ver: Sidney Chalhoub, Visões da liberdade: uma história das últimas décadas da escravidão na Corte, São Paulo: Companhia das Letras, 1990, pp. 175-81. 
a monarquia e o gabinete Cotegipe acerca da abolição. Escravas como Maria, do Recife, haviam aberto caminho para a liberdade ao mobilizar ativamente- em lugar de receber passivamente - os mecanismos do patronato, que seguia sendo elemento fundamental da cultura política brasileira. ${ }^{81}$

As relações de patronato eram significativas quando sociedades abolicionistas e vereadores estudavam listas de escravos candidatos à liberdade. Prisciano de Albuquerque Lins, senhor de engenho que em cerimônias em 1874 libertara seus escravos, pediu, em junho de 1881, um favor a João Ramos, da Sociedade Nova Emancipadora. Explicou que Eustáquio, pardo liberto, precisava de 200 mil réis para completar o valor necessário para libertar sua filha, Nympha. O presidente da Sociedade Nova Emancipadora sugeriu que se fizesse atender ao pedido "[...] não só porque a quantia é pequena, mas principalmente por ser o major Prisciano um cidadão digno nos seus actos em relação ao elemento servil". ${ }^{82}$ De maneira similar, antes da reunião anual do Club Abolicionista para seleção de escravos a serem libertados, em 1881, uma carta enviada ao Jornal do Recife exigia que a escrava Rufina não fosse preterida em favor de escravos com melhores "conexões". A carta ilustrava a importância de quem advogava em nome de um escravo, ${ }^{83}$ além de enfatizar os persistentes esforços de escravos na direção de sua própria liberdade, mesmo quando negligenciados por comitês de fundos de emancipação.

\section{Bancando a liberdade}

Ao contrário do fundo de emancipação nacional, patrocinado pelo governo, as atividades necessárias para financiar fundos locais de emancipação forjaram elos entre o movimento abolicionista e uma grande variedade de atores locais. Tanto no Rio quanto no Recife, os fundos provinham em grande parte de doações e contatos de negócios. ${ }^{84}$ Para seu primeiro evento, a Nova Emancipadora assegurou uma apresentação especial de uma companhia viajante de teatro, com todos os proventos destinados ao fundo de emancipação. ${ }^{85}$ Concertos, kermesses e outros

${ }^{81}$ Graham, Patronage, pp. 1-7.

82 Atas Nova Emancipadora, 5 de junho de 1881, IAHGP, CSNE.

83 Jornal do Recife, 10 de setembro de 1881, p. 2.

${ }^{84}$ Estatutos Nova Emancipadora, pp. 3-4. Outras sociedades abolicionistas no Recife também dependiam das contribuições dos seus membros.

85 Diário de Pernambuco, 5 de outubro de 1880, p. 1. A companhia, Maravilhas, era dirigida pelo conde de Castiglioni. 
eventos públicos foram realizados no Rio de Janeiro para o Livro de Ouro. ${ }^{86}$ A Câmara Municipal do Rio de Janeiro arrecadou para o Livro um imposto de um mil réis entre os residentes municipais que tinham os meios para pagá-1o ${ }^{87}$ - o que gerou acusações de que a verba arrecadada, como a maior parte dos fundos municipais, estava sendo mal administrada por uma Câmara tão notória pela corrupção que fora apelidada de "mar de lama municipal". No Rio, assim, a questão da emancipação dos escravos rapidamente desdobrou-se em questões mais amplas acerca das dinâmicas do governo local. ${ }^{88}$

As doações para os fundos locais contavam com uma ampla base de contribuintes. O Club Abolicionista do Recife inicialmente procurou doações de professores e estudantes da Escola de Direito do Recife, de onde vieram muitos de seus membros. Seus esforços logo se expandiram em comissões de jovens que solicitavam contribuições nos maiores bairros da cidade: Recife, Boa Vista, São José e Santo Antônio. Além da arrecadação de dinheiro, essas comissões sensibilizavam a população a respeito da causa abolicionista. Os desdobramentos dessa movimentação eram publicados em jornais, preenchendo-se diversas colunas com as pequenas contribuições de uma ampla base de doadores. Ao ver seus nomes impressos e associados ao abolicionismo, pessoas comuns eram atraídas e, assim, ajudavam a impulsionar o movimento para além dos limites da arena política formal, transformando-o numa preocupação social e pública. A Câmara Municipal do Rio utilizou-se também de comissões locais de conselheiros, juízes de paz e subdelegados para angariar fundos em vizinhanças específicas, ressoando a estratégia do abolicionismo urbano de focar seus esforços em ruas e áreas previamente determinadas. ${ }^{89}$

86 "Regulamento substitutivo", Boletim, 10 de julho de 1885, p. 26, e Boletim, 14 de outubro de 1886, p. 4.

87 Boletim, 2 de junho de 1885, pp. 102-3.

${ }_{88}$ A respeito das acusações, ver: "Assumptos Municipaes", Gazeta da Tarde, 12 de dezembro de 1887, p. 1. O jornal britânico The Anglo-Brazilian Times, com sede no Rio, havia anteriormente desaprovado as "insondáveis profundezas da negligência e incapacidade municipais" no Rio, acrescentando que, em todo o Brasil, "o propósito da eleição de municipais parece ser as próprias eleições e o favorecimento de (cabides de empregos?)". Em sua campanha para a eleição municipal em 1886, Patrocínio explicitamente diferiu entre sua plataforma abolicionista e a corrupção e o "forrar de bolsos" característicos da Corte. "A municipal mudhole", The AngloBrazilian Times, 16 de janeiro de 1875, p. 3; "Eleição Municipal", Gazeta da Tarde, 28 de junho de 1886, p. 1; "Eleição Municipal", Gazeta da Tarde, 5 de dejulho 1886, p. 2.

89 "Resolução, Livro de Ouro", Boletim, 2 de junho de 1885, p. 103. Para listas de doadores, ver: AGCRJ, E:E, Book 6.1.41, 19-24; Boletim, 25 de julho de 1885, pp. 27-8. 
O bancamento da liberdade era também internacionalmente visível - uma doação de cinco pounds foi enviada desde Londres. ${ }^{90}$

As doações guardavam implicações para a política local que iam muito além da intenção de libertar escravos. Doações feitas ao Livro de Ouro eram, por exemplo, uma forma de assegurar favores da Câmara. Em junho de 1886, a Companhia Industrial Fluminense pediu que a Câmara reconsiderasse a decisão de remover seu quiosque de uma rua da cidade, onde aparentemente obstruía o tráfego. Satisfeitos com a oferta de 500 mil réis "feita espontaneamente pelo peticionário ao Livro de Ouro", os vereadores concordaram que, afinal de contas, o quiosque não impunha tantos prejuízos assim ao tráfego local. ${ }^{91}$ Quando Francisco Machado de Freitas, que vendia cebolas na Praça do Mercado, decidiu que venderia também peixe fresco, ofereceu à Câmara 500 mil réis para "a educação municipal e o Livro de Ouro". Os conselheiros deferiram apenas parte de suas solicitações, permitindo que vendesse peixe seco, mas aceitaram sua doação. ${ }^{92}$

O bancamento da liberdade também criava meios para reforçar os perfis públicos e as carreiras de negócio dos doadores masculinos. ${ }^{93}$ Proprietários que concediam manumissões sem indenizações e doadores, especialmente aqueles que ofereciam grandes contribuições, eram em sua maioria homens. Entre a elite, com maior frequência do que as mulheres, os homens possuíam renda disponível e o incentivo de uma carreira pública que pudesse ser fortalecida por meio da munificência pública. Ainda assim, mulheres figuravam de forma desproporcional entre os proprietários que libertavam escravos em troca de indenizações dos fundos. De maneira geral, tais proprietárias libertavam um ou dois de seus escravos, espelhando padrões de propriedade urbana de escravos segundo os quais muitas pessoas possuíam apenas poucos escravos para serviços domésticos ou ganho. ${ }^{94}$

90 A doação do "conselheiro delegado do thesouro nacional" chegou em junho de 1888, após a abolição ter sido finalmente declarada, e foi encaminhada para fins de caridade geral no Município Neutro. Boletim, 28 de junho de 1888, p. 23.

91 Boletim, 25 de junho de 1886, p. 168.

92 Boletim, 17 de março de 1887, p. 84.

93 Isso vai ao encontro da ideia de Richard Graham acerca de uma atitude diante da vida política baseada na necessidade de criar uma clientela local. Graham, Patronage, p. 22.

94 A Confederação Abolicionista estimou, em 1887, que havia ainda 7.421 escravos e 3.189 proprietários no Município Neutro - uma média de 2,3 escravos por proprietário. "Representação da Confederação Abolicionista ao presidente e mais vereadores da Câmara municipal da côrte", 1 de maio de 1887, Boletim, 14 de maio de 1887, pp. 79-80. 
Em cada uma dessas cidades, as mulheres somavam cerca de $50 \%$ dos proprietários que concediam manumissões - número muito expressivo quando comparado à quantidade de mulheres nos quadros mais amplos dos proprietários de escravos. ${ }^{95} \mathrm{O}$ ato de conceder a manumissão a um escravo era também possivelmente compreendido como uma atitude "feminina", entrelaçando-se a uma crescente "feminização" das noções de caridade. ${ }^{96}$ Dadas as escassas possibilidades de emprego para mulheres, bem como os amplos números de mulheres solteiras ou viúvas, a decisão de conceder a manumissão a um escravo também pode ser interpretada como reflexo da pobreza de muitas delas. Tal condição poderia tentar essas mulheres à possibilidade de obter lucro rápido vendendo seus escravos restantes enquanto valiam ainda alguma coisa antes da abolição, mesmo quando dependiam de seu trabalho. ${ }^{97}$ Era também bastante mais comum que mulheres possuíssem outras mulheres como escravas, geralmente empregando-as em suas próprias atividades de trabalho considerado feminino. ${ }^{98}$ Qualquer que seja a explicação, as proporções entre os sexos dos doadores e proprietários que concediam manumissões chamam atenção a novas questões sobre gênero, propriedade de escravos e atividades abolicionistas que demandam a atenção de futuras pesquisas.

\section{Escravos com poupanças}

A maior parte dos escravos que se ajoelhavam "agradecidamente" para

95 Ainda não há um estudo sistemático acerca da propriedade escrava em Pernambuco no final do século XIX. Entretanto, inventários post-mortem sugerem que menos de 10\% dos proprietários de escravos no Recife eram mulheres na década de 1880. Para uma análise preliminar ver: José Raimundo Vergolino e Flávio Rabelo Versiani, "Posse de escravos e estrutura da riqueza no agreste e sertão de Pernambuco, 1770-1887", Revista de Estudos Econômicos, v. 33, n. 2 (2003), pp.353-93. No Rio, a população branca era predominantemente masculina. Isso, junto ao maior poder de remuneração e compra dos homens, comparados às mulheres, sugere que homens compunham a maioria entre os proprietários de escravos, além de possuir maior quantidade de escravos individualmente. Recenseamento da população do Municipio Neutro e Paraná a que se procedeu em 1 de agosto de 1872, Rio de Janeiro: n.p., 1872, p. 58.

96 Kittleson, "Women and Notions of Womanhood", pp. 101-5.

97 Maria Odila Leite da Silva Dias, Power and Everyday Life: The Lives of Working Women in Nineteenth-Century Brazil, Cambridge: Polity Press, 1995, pp. 9-19, 28-32, 74-93; Karasch, Slave Life, pp. 342-45.

98 Zephyr L. Frank, Dutra's World: Wealth and Family in Nineteenth-Century Rio de Janeiro, Albuquerque: University of New Mexico Press, 2004, p. 160. Embora o estudo de Frank trate de um período anterior, o padrão de propriedade escrava marcado pela diferenças de gênero parece ser aplicável também ao contexto de que tratamos. 
receber suas cartas de alforria nas cerimônias havia, em boa medida, proporcionado sua própria liberdade. E o faziam empregando as ferramentas de que qualquer ator político da sociedade imperial precisava, estrategicamente dispondo não apenas do patronato, mas de informação e dinheiro.

Os escravos estavam plenamente cientes da existência dos fundos de emancipação. Além dos rituais públicos, a constante publicidade em jornais locais mantinha os fundos vivos aos olhos do público. Os organizadores dos fundos supunham que a publicidade escrita atingiria tanto os escravos como seus senhores. Em setembro de 1880, o Club Abolicionista do Recife convidava explicitamente "todos os escravos que estiverem nas condições de preencher os requisitos são convidados a submeter petições a comissão". Os anúncios do Livro de Ouro não mencionavam os próprios escravos, mas os conselheiros, que recebiam múltiplas petições de escravos, sabiam que eles estavam cientes das possibilidades que o fundo os oferecia. Oficialmente, escravos letrados - especialmente mulheres - eram extremamente raros. Entretanto, por meio de diversas relações com pessoas livres e libertas no trabalho, na família e mesmo na rua, os escravos urbanos há muito haviam utilizado as ferramentas da cultura escrita para ter acesso à manumissão no Brasil - assim como ocorreu em outras partes da América Latina. Petições para os fundos chegavam desde lugares muito além das cidades do Recife e do Rio de Janeiro, indicando que havia amplas redes de informação que se estendiam para além das fronteiras urbanas. ${ }^{99}$

Cientes dos fundos, os escravos precisavam transformar conhe-

99 A respeito do anúncio no Recife, ver: Diário de Pernambuco, 18 de setembro de 1880, p. 4. Para exemplos de anúncios do Livro de Ouro no Rio de Janeiro, ver: "Libertações de Escravos por Conta dos Donativos do Livro de Ouro", Jornal do Commercio, 19 de junho de 1885, p. 4. Em 1872, 61 homens e 26 mulheres entre os 12.000 escravos no Recife, e 220 homens e 109 mulheres dos 48.919 escravos no Rio eram oficialmente letrados. Recenseamento da População de Pernambuco a que se procedeu no dia 1 de agosto de 1872, University of Chicago Microfilm Project, Reel 19120, 1872, p. 214; Recenseamento do Municipio Neutro 1872, pp. 58-9. A respeito da "democratização" da vida das ruas e a transmissão de informação por meio da cultura oral ou de imagens, ver: Mello, A República Consentida, capítulo 1. Sobre escravos e a cultura letrada no Peru, ver: José Ramón Jouve Martín, Esclavos de la ciudad letrada: esclavitud, escritura y colonialismo en Lima (1650-1700), Lima: Instituto de Estudios Peruanos, 2005. Embora escravos urbanos vivessem num contexto particularmente propício para o uso da cultura escrita, escravos de áreas rurais certamente também o faziam. Ver: Sandra Lauderdale Graham, Caetana Says No: Women's Stories from a Brazilian Slave Society, Cambridge: Cambridge University Press, 2002. Sobre os íntimos vínculos entre ações abolicionistas (inclusive de escravos) em áreas rurais e urbanas, ver: Maria Helena Machado, $O$ plano e o pânico: os movimentos sociais na década da abolição, Rio de Janeiro: UFRJ/EDUSP, 1994. 
cimento em ação. Bancar a liberdade dependia de negociações entre financiadores, escravos e proprietários. Sendo que a "Lei do Ventre Livre" somente obrigava proprietários a libertar escravos que pudessem prover remuneração total de seus valores estabelecidos, pessoas escravizadas que precisavam de uma terceira parte para completar tais valores tinham que advogar suas causas a proprietários e terceiros. Um mecanismo fundamental para tanto foi o uso de petições, em geral feitas diretamente por escravos em reuniões de sociedades abolicionistas. Trezentos apelos dessa natureza foram registrados pela Sociedade Nova Emancipadora entre 1881 e 1884, sugerindo que uma larga parcela dos escravos libertados havia feito significativos esforços no sentido de alcançar sua liberdade. Embora documentos que, de fato, sobrevieram ao tempo, como os de Maria e Maria Rosa, sejam raros, podemos compreender que eles representam a ponta de um iceberg muito maior de atividade escrava sob o véu do bancamento da liberdade e do registro histórico. ${ }^{100}$

No Recife, as escravas se destacaram entre as pessoas que proviam a maior parte de seus valores indenizatórios (ver Tabela 1). A única lista remanescente de escravos libertos admite novas compreensões acerca do papel dos escravos no processo de manumissão. O Club Abolicionista, durante a campanha de 1881-1882 de seu fundo de emancipação, seguiu suas diretrizes em relação a questões de gênero, sendo que 30 dos 33 escravos selecionados (91\%, portanto) eram mulheres, e em sua maioria tinham entre 20 e 30 anos. Apenas quatro das mulheres libertas - e nenhum dos três homens - tinham mais de 50 anos. Na média, os pecúlios amealhados por mulheres representavam $71 \%$ do valor total de suas indenizações, e em alguns casos essa proporção era ainda mais alta. Uma mulher chamada Maria, de 50 anos de idade, forneceu 500 mil réis dos 580 mil réis em que seu preço fora avaliado (86\% do valor total). ${ }^{101}$ De certa forma, tais mulheres seguiram uma tradição de aquisição de sua própria liberdade praticada largamente antes da lei de 1871. Entretanto, após essa data, a compra da própria liberda-

${ }^{100}$ Atas Nova Emancipadora, s.d., IAHGP, CSNE. Para outras fascinantes iniciativas escravas, que merecem maior atenção do que podemos oferecer aqui, ver: AGCRJ, E:E, Book 6.2.6, junho-julho de 1885 , p. 7, 24, 28, 34 .

${ }^{101}$ Diário de Pernambuco, 5 de outubro de 1882, p. 2 . A data corresponde a 29 de setembro de 1881 a 28 de setembro de 1882 . 
de adquiriu novos significados: proprietários cujos escravos tivessem a quantia necessária para pagar por sua liberdade não mais poderiam impedi-los de fazê-lo. Isso representava uma mudança política tremendamente significativa no que dizia respeito ao equilíbrio de poderes entre proprietário, escravos e estado. As contribuições financeiras dos escravizados para "bancar a liberdade" assumiram um poderoso novo significado nesse novo contexto. ${ }^{102}$

Dados sobre a contribuição de escravos para as manumissões através do Livro de Ouro da Corte não foram mantidos pela Câmara, mas, evidentemente, a formação de pecúlio e a barganha dos escravos, especialmente das mulheres, foram centrais para o processo do bancamento da liberdade. ${ }^{103}$ Em novembro de 1887 , ciente da aproximação da cerimônia de emancipação de dezembro, uma jovem mulher escravizada, Josepha, propôs um acordo à Câmara: ela solicitou 200 mil réis, que seriam adicionados aos 100 mil réis que já havia poupado. Somando, assim, os 300 mil réis reivindicados pelos herdeiros de seu proprietário, Josepha iria conseguir sua liberdade. ${ }^{104}$ Mas, parece ter sido outra a negociação com a Câmara, devido ao fato de ela ter logrado ser liberta por 150 mil réis, ou pela metade do preço, Josepha finalmente fechou o processo.

Josepha foi uma das 766 pessoas libertas com indenização no Rio de Janeiro por meio do Livro de Ouro, das quais, $76 \%$ eram mulheres (ver Tabela 2). ${ }^{105}$ Ainda assim, a existência de uma porcentagem masculina mensurável, contrariava as intenções da Câmara de focar suas atenções em mulheres. A porcentagem de mulheres decresceu ao longo do tempo, passando de $100 \%$ na primeira cerimônia em julho de 1885 para apenas $57 \%$ na sexta cerimônia, em setembro de 1886. Logo depois, o vereador Germack Possolo protestou que "o numero [sic] de

${ }^{102}$ Sobre o significado político das negociações de compra da liberdade pelos próprios escravos, ver: Chalhoub, Machado de Assis, pp. 260-64, e Mendonça, Entre a mão e os anéis, pp. 25464. Fundos locais de emancipação adotaram a redução gradual dos preços máximos de escravos antes que a prática fosse formalizada na lei de setembro de 1885 . "Regulamento substitutivo", Boletim, 10 de judelho 1885, p. 26.

${ }^{103}$ Sobre a prioridade dada a mulheres com algum pecúlio, ver: Boletim, 2 de junho de 1885, pp. 102-3.

${ }^{104}$ Josepha para o Conselho Municipal, s.d. [aprox. novembro, 1887], AGCRJ, E:E, Book 6.2.9, 161-2; Boletim, 2 de dezembro de 1887.

${ }^{105}$ Maiores detalhes sobre as 31 pessoas libertadas gratuitamente não estavam disponíveis, de modo que elas não foram incluídas nessa discussão. 
libertandos do sexo masculino quasi [sic] igualou aos do outro sexo; entretanto o espirito [sic] das emancipações municipaes [sic] tem justamente o intuito contrario". A Câmara resolveu libertar apenas mulheres no futuro, especialmente aquelas com filhos. ${ }^{106}$ A cerimônia seguinte libertou apenas mulheres. Ainda assim, nas duas últimas cerimônias de 1887, as proporções de homens entre o total de libertos foram, respectivamente, $44 \%$ e $35 \%$. Isso talvez decorra do fato de que, numa cidade cujos lares dependiam principalmente do trabalho doméstico feminino, a ansiedade a respeito do pós-abolição era considerável. ${ }^{107}$ Alguns proprietários talvez tenham escolhido manter consigo escravas domésticas, concedendo a manumissão a escravos homens.

Também contradizendo os objetivos da Câmara, a maior parte das mulheres libertadas no Rio de Janeiro não tinha filhos, e aquelas que eram mães geralmente tinham apenas um filho. ${ }^{108}$ Talvez não tenha sido possível encontrar mães suficientes cujos donos quisessem manumiti-las. As mulheres escravizadas no Rio de Janeiro tinham baixos índices de fertilidade, e criar os filhos era bastante difícil para criadas domésticas. ${ }^{109}$ Era provável, também, que os proprietários fossem relutantes quanto a perder o trabalho dos ingênuos libertando suas mães, assim como resistiam à opção oferecida pela Lei de 1871 de entregá-los aos cuidados do estado. ${ }^{110}$ Contudo, a maior parte das mulheres libertadas no Rio de Janeiro tinha idade para tornar-se mãe. Seu futuro potencial para dar à luz a primeira geração de brasileiros inteiramente livres era fundamental à decisão de libertá-las, a despeito das dificuldades que o mercado de trabalho urbano pudesse criar para que isto realmente acontecesse. A maternidade, simultaneamente, informava as petições e

\footnotetext{
${ }^{106}$ Boletim, 16 de setembro de 1886, p. 94, 99.

${ }^{107}$ Sandra Lauderdale Graham, House and Street: The Domestic World of Servants and Masters in Nineteenth-Century Rio de Janeiro, Austin: University of Texas Press, 1988, p. 22; ver também: Boletim, 19 de setembro de 1888, p. 65; "Regulamento do Serviço Domestico", Boletim, 4 de outubro de 1888, pp. 3-4.

${ }^{108}$ Notavelmente, $19 \%$ das pardas e apenas $12 \%$ das pretas libertadas no Rio tinham filhos. Cerca de um terço dos escravos libertados eram descritos como pardos e os demais, como pretos. Sobre alforrias e cor da pele, ver: Karasch, Slave Life, pp. 350-52; Stuart Schwartz, "The Manumission of Slaves in Colonial Brazil: Bahia, 1684-1745", Hispanic American Historical Review, v. 54, n. 4 (1974), pp. 612-18.

${ }^{109}$ Mary Karasch, "Anastácia and the Slave Women of Rio de Janeiro", in Paul E. Lovejoy (org.), Africans in Bondage: Studies in Slavery and the Slave Trade (Madison: University of Wisconsin Press, 1986), pp. 83-6, 100.

${ }^{110}$ Chalhoub, Machado de Assis, pp. 274-75.
} 
iniciativas de muitas mulheres como Maria e Maria Rosa. Por meio de práticas e rituais de bancamento da liberdade, os fundos de emancipação tornaram-se um palco em que atores políticos locais encenavam os dramas cotidianos da política nacional. ${ }^{111}$

\section{Conclusão}

O estudo dos fundos de emancipação locais lança luzes importantes sobre as dinâmicas do abolicionismo e as mudanças mais amplas e profundas da prática política no Brasil da década de 1880. Por muito tempo mal compreendidos, em razão dos números relativamente baixos de escravos libertados, os fundos de emancipação fundamentavam duas vertentes centrais da abolição: uma vibrante e frequentemente antagônica troca entre os âmbitos políticos local e nacional, que desmente qualquer ideia simplista de que a política brasileira do século XIX fosse elaborada a partir da capital para as demais províncias, e uma constante interação entre projetos abolicionistas e o envolvimento orgânico de um público extenso que incluía os próprios escravizados, fazendo do bancamento da liberdade muito mais que uma simples iniciativa abolicionista verticalizada.

As implicações políticas dos fundos locais de emancipação mudaram ao longo dos anos 1880, refletindo e influenciando os altos e baixos da política antiescravista daquela década. Inicialmente, a mobilização em torno da crítica ao fundo nacional de emancipação fez dos fundos locais uma feição emblemática do ativismo abolicionista pelo Brasil. No transcorrer de 1883 a 1885 , em meio à polarização entre governo nacional e movimento abolicionista, os significados dos fundos locais sofreram mudanças. Mesmo quando as posições abolicionistas mais combativas passaram a repensar a emancipação indenizada como um ato fundamentalmente conservador, a virada pró-escravista do gabinete Cotegipe, em 1885, fez dos fundos locais de emancipação uma fonte importante de oposição.

A mobilização popular e as iniciativas criativas pela liberdade,

${ }^{111}$ A prática de libertar mulheres e crianças também se aplicava a outras ideias sobre escravidão e abolição envolvidas por questões de gênero. Elas eram vistas como menos ameaçadoras fisicamente do que homens adultos, num momento de grande ansiedade das elites a respeito da ordem e do controle sociais após a abolição. Para um exemplo dessa lógica, ver: "Novos aspectos", A Revista Illustrada, 30 de abril de 1886, p. 3. 
relacionadas aos fundos locais, asseguraram menos o decréscimo da população escravizada do que a ampliação do espectro político nacional. Grupos sociais diversos, historicamente excluídos dos debates políticos, empurraram a agenda política do abolicionismo em novas direções. Ao participar do bancamento da liberdade, mobilizando recursos do patronato, petições, informações e economias, pessoas comuns, especialmente mulheres como Maria e Maria Rosa, criaram novos espaços políticos própios, avançando numa causa que o governo nacional preferiu ignorar.

Tais movimentações políticas eram produzidas localmente e sentidas nacionalmente, sendo, além disso, comentadas em âmbito internacional. Falando em Madri para a Sociedade Abolicionista Espanhola, pouco depois de Espanha e Brasil terem aprovado suas respectivas "leis do Ventre Livre”, em 1870 e 1871, o professor universitário Salvador Torres Aguilar afirmou que a lei brasileira ia mais longe no cerceamento da escravidão do que fazia a espanhola Lei Moret de 1870. Ele descreveu como ações fora do parlamento, incluindo aquelas das primeiras sociedades emancipacionistas, haviam ajudado a colocar a lei brasileira de 1871 na agenda política nacional. A própria lei, disse ele, previa iniciativas privadas e nacionais de manumissão compensada. A isto, comparou o rígido controle colonial sobre Cuba e Porto Rico, onde o governo espanhol "não imita o governo brasileiro em se colocar, como deveria, na liderança dessa nobre propaganda; nas Antilhas, a existência de sociedades de emancipação é proibida; [...] não há liberdade de imprensa para abolicionistas...". E acrescentou, amargamente: "Os senhores acham [...] que as coisas que discutimos e fazemos aqui [...] são ao menos conhecidas nas Antilhas? Pensam que podemos nos entender com os escravos, cujo benefício procuramos? Não"! ${ }^{112}$

Embora a colocação comparativa de Torres Aguilar fique além do nosso alcance, é instrutivo observar o processo brasileiro de bancamento da liberdade do ponto de vista dos ativistas da Espanha, o outro poder do Novo Mundo que ainda mantinha a escravidão na década de $1880 .{ }^{113}$

${ }^{112}$ Sociedad Abolicionista Española, La abolición de la esclavitud en el Brasil y en España. Discurso pronunciado por d. Salvador Torres Aguilar, catedrático de la Universidad de Madrid, Madrid: Secretaria de la Sociedad Abolicionista Española, 1872, pp. 6-8; 10-3.

${ }^{113}$ Para uma análise comparativa do final da escravidão no Brasil e em Cuba, ver: Christopher SchmidtNowara, "Empires against Emancipation: Spain, Brazil, and the Abolition of Slavery", Review, v. 31, n. 2 (2008), pp. 101-19; Celso Castilho, "Brisas atlánticas: la abolición gradual y la conexión 
Enquanto abolicionistas brasileiros condenavam a ineficiência do fundo de emancipação nacional e utilizavam os fundos locais para mobilizar a opinião popular e "entender com os escravos, cujo benefício procuramos", chegando eventualmente a rejeitar a própria ideia de emancipação compensada, seus pares do outro lado do Atlântico notaram sua própria inabilidade de reproduzir tais desdobramentos em Porto Rico e em Cuba. Joaquim Nabuco, saudado de forma arrebatadora pela Sociedade Abolicionista Espanhola numa viagem à Madri, em janeiro de 1881, queixou-se das limitações da Lei de 1871. O abolicionista espanhol Rafael da Labra contrapôs-se a ele, desejando que as circunstâncias em Cuba fossem mais parecidas às do Brasil, e perguntou:

Não seria legítimo solicitar os poderes do Estado para permitir, em Cuba [...] a formação de sociedades que pudessem contribuir para o grande trabalho da redenção dos escravos, fosse agitando opiniões abolicionistas (ou) fomentando manumissões parciais [...]? ${ }^{114}$

Ao mesmo tempo, no Brasil da década de 1880, escravizados e seus aliados livres moldavam o bancamento da liberdade de maneira que os criadores dos fundos de emancipação não haviam imaginado, construindo não apenas "liberdades concedidas", mas também "liberdades conquistadas". ${ }^{115}$ Aliás, os novos espaços de ação política abertos pelo processo do bancamento da liberdade ajudaram diferentes sujeitos a definir o que significava a liberdade. ${ }^{116}$ Em Madri, Nabuco havia declarado solenemente a necessidade de "dar uma pátria" aos escravos

brasileña-cubana”, in Rina Cáceres e Paul Lovejoy (orgs.), Haití: Revolución y Emancipación (San José: Editorial UCR, 2008), pp. 128-38; Laird W. Bergad, The Comparative Histories of Slavery in Brazil, Cuba, and the United States, Nova York: Cambridge University Press, 2007, capítulo 8; Camillia Cowling, "Matrices of Freedom: Women of Color, Gender, and the Ending of Slavery in Havana and Rio de Janeiro, 1870-1888" (Tese de Doutorado, University of Nottingham, UK, 2007); Drescher, "Brazilian Abolition"; Lamounier, "Between Slavery"; Rebecca J. Scott, Seymour Drescher, Hebe Mattos, George Reid Andrews e Robert Levine, Exploring the Meaning of Freedom in Post-emancipation Societies, Durham: Duke University Press, 1988.

${ }^{114}$ Sociedad Abolicionista Española, Sesión del 23 de Enero de 1881, 4-6, 11-8. A escravidão já havia sido abolida em Porto Rico, então (ano de 1873).

${ }^{115}$ A lógica que os informava está em: Kim D. Butler, Freedoms Given, Freedoms Won: AfroBrazilians in Post-Abolition São Paulo and Salvador, New Brunswick: Rutgers University Press, 1998.

${ }^{116}$ Sobre os "significados da liberdade" ver Hebe Maria Mattos, "Os combates da memória: escravidão e liberdade nos arquivos orais de descendentes de escravos brasileiros", Tempo, v. 6, n. 3 (1998), p. 125, 136; Ana Lugão Rios e Hebe Mattos, Memórias do cativeiro: família, trabalho e cidadania no pós-abolição, Rio de Janeiro: Civilização Brasileira, 2005, p. 49. 
brasileiros. Após a Abolição, a cidadania direta ainda seria negada à maior parte dos libertos e a todas as libertas. ${ }^{117}$ Mesmo assim, as experiências de bancamento da liberdade não seriam esquecidas após a Abolição de 1888 ou a proclamação da República em 1889. É possível que futuros estudos mostrem como tais experiências instrumentalizaram brasileiros excluídos das elites a participar da vida política, a despeito da pobreza e da marginalização. E, da mesma forma como as experiências de bancamento da liberdade não foram esquecidas por seus partícipes, elas merecem ser lembradas pelos historiadores e historiadoras do Brasil hoje em dia.

\section{Tabela 1: Escravos libertos pelo Fundo de Emancipação do Club Abolicionista, Recife, 1881-1882}

\begin{tabular}{lccccc}
\hline $\begin{array}{c}\text { N. de Escravos } \\
\text { Libertos }\end{array}$ & $\begin{array}{c}\text { Idade } \\
\text { média }\end{array}$ & $\begin{array}{c}\text { Valor } \\
\text { médio }\end{array}$ & $\begin{array}{c}\text { Pecúlio } \\
\text { médio do } \\
\text { escravo }\end{array}$ & $\begin{array}{c}\text { Pecúlio do } \\
\text { escravo como } \\
\text { porcentagem } \\
\text { média do } \\
\text { valor }\end{array}$ \\
\hline Mulheres & 30 & 34 & 336 & 241 & 71 \\
Homens & 3 & 28 & 370 & 270 & 73 \\
Total & 33 & 33 & 339 & 244 & 72 \\
\hline
\end{tabular}

Fonte: Diário de Pernambuco (Recife), 5 Outubro de 1882, p. 2. Os dados são para o período entre 29 de setembro de 1881 a 28 de setembro de 1882 .

${ }^{117}$ De fato, uma reforma eleitoral em 1881 houvera recentemente reduzido o acesso amplo ao sufrágio masculino, passando de mais de um milhão a menos de 150.000 eleitores. Graham, Patronage, p. 184. A respeito da reforma, ver Sidney Chalhoub, "The Politics of Silence: Race and Citizenship in Nineteenth-Century Brazil", Slavery and Abolition, v. 27, n. 1 (2006), pp. 73-87. Para um panorama dos debates em torno da cidadania negra no pós-Abolição, ver Olívia Maria Gomes da Cunha e Flávio dos Santos Gomes (orgs.), Quase-cidadão: histórias e antropologias da pós-emancipação no Brasil, Rio de Janeiro: Fundação Getúlio Vargas, 2007. 
Tabela 2: Escravos libertos pelo fundo municipal Livro de Ouro da cidade do Rio de Janeiro, 1885-1887 ${ }^{\mathrm{b}}$

\begin{tabular}{|c|c|c|c|}
\hline & $\begin{array}{c}\text { Número de } \\
\text { escravos libertos }\end{array}$ & Idade média & Preço médio ${ }^{a}$ \\
\hline Mulheres com filhos & 116 & 29 & N/A \\
\hline Mulheres sem filhos & 418 & 30 & N/A \\
\hline Total de mul heres & 582 & 30 & 241 \\
\hline Total de homens & 184 & 32 & 210 \\
\hline Total & 766 & 30 & 234 \\
\hline \multicolumn{4}{|c|}{ 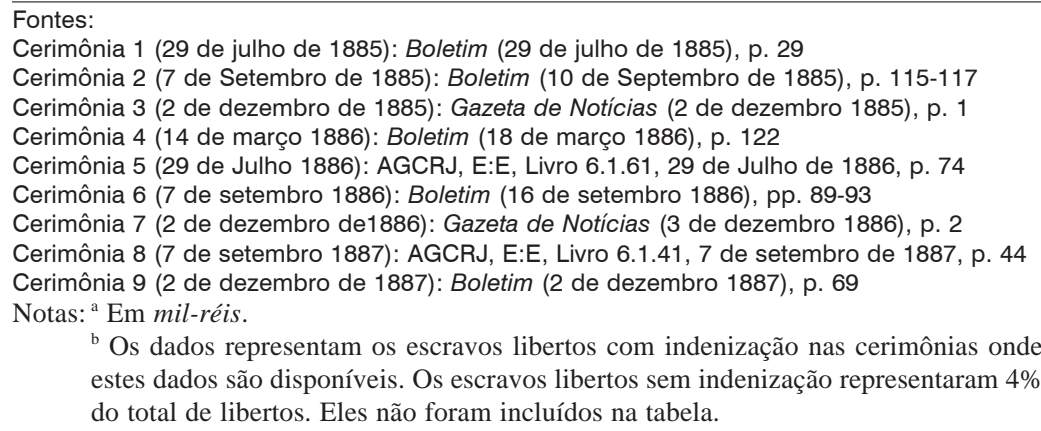 } \\
\hline
\end{tabular}

Texto apresentado em 12 de abril de 2012 e aceito em 21 de junho de 2012 


\title{
Resumo
}

Voltado às amplas repercussões da mobilização abolicionista dos anos 1880 , este artigo ressalta os fundos de emancipação locais no Rio de Janeiro (Corte) e no Recife como espaços importantes para a articulação da política popular. Examinamos dois tipos de fundos locais, o primeiro criado por iniciativas populares no Recife, e o segundo produto da câmara municipal da Corte. Salientamos, na primeira parte, que os significados políticos dos fundos de emancipação mudaram ao longo da década de 1880 , sendo esta trajetória um exemplo do percurso aturdido da política da abolição. Os fundos de emancipação locais também alteraram as dinâmicas tradicionais da política, modificando as interações entre as esferas locais e nacionais, entre grupos populares e a elite. $\mathrm{Na}$ segunda parte, analisamos as operações cotidianas dos fundos. $\mathrm{O}$ uso de rituais públicos e a procura de donativos locais estenderam o alcance dos fundos a setores sociais previamente afastados do processo político. Os próprios escravos, particularmente as escravas, utilizaram seu pecúlio, informações colhidas nas ruas e o patrocínio de maneiras inovadoras para ganhar sua liberdade, ao invés de recebê-la passivamente por meio dos fundos. Enfim, os fundos de emancipação merecem a atenção dos historiadores porque se intercalaram de maneira importante com outros fenômenos de pressão política e social, como fugas de escravos e lutas jurídicas, que transtornaram a política brasileira na década de 1880 e aceleraram o decreto da Abolição da escravatura.

Palavras-chave: escravidão - política - abolição - abolicionismo - gênero

\begin{abstract}
Situating its approach within the broader context of the abolition movement in the 1880s, this article examines local emancipation funds in the cities of Rio de Janeiro and Recife as important expressions of grassroots politics. The article considers two different local funds, one created by popular initiatives in Reci$f e$, and another created by Rio's city council. The first part of the article shows that emancipation funds changed over the course of the 1880s, accompanying changes in traditional policy-making dynamics and transforming interactions between local and national spheres, as well as between grassroots groups and the elite. The second part of the article focuses on the everyday operations of the funds. By using public rituals and searching for local donors, the funds expanded their reach to social sectors previously disconnected from the political process. Rather than waiting passively to receive freedom through the funds, slaves, especially women, utilized their peculios as well as information obtained on the streets in creating innovative strategies to obtain their freedom. Emancipation funds merit attention from historians because they combined in important ways with other forms of political and social pressure such as flight from slavery and legal battles in transforming Brazilian politics in the 1880s, thus hastening the arrival of the decree abolishing slavery.
\end{abstract}

Keywords: slavery - politics - abolition - abolitionism - gender 